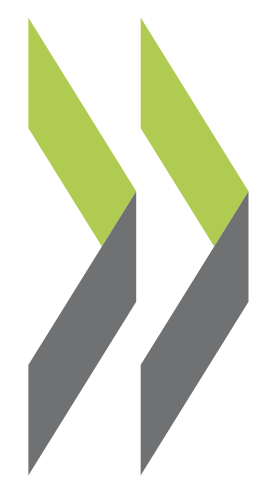

OECD Economics Department Working Papers No. 1104

$$
\begin{array}{r}
\text { New Indicators } \\
\text { of Competition Law } \\
\text { and Policy in } 2013 \\
\text { for OECD and non-OECD } \\
\text { Countries }
\end{array}
$$

\section{Enrico Alemani, Caroline Klein, Isabell Koske, Cristiana Vitale, Isabelle Wanner}


Organisation de Coopération et de Développement Économiques

Organisation for Economic Co-operation and Development

12-Dec-2013

ECONOMICS DEPARTMENT

English - Or. English

NEW INDICATORS OF COMPETITION LAW AND POLICY IN 2013 FOR OECD AND NON-OECD COUNTRIES

OECD ECONOMICS DEPARTMENT WORKING PAPERS No. 1104

By Enrico Alemani, Caroline Klein, Isabell Koske, Cristiana Vitale and Isabelle Wanner

All Economics Department Working Papers are available through OECD's Internet website at http://www.oecd.org/eco/Workingpapers

JT03350386

Complete document available on OLIS in its original format

This document and any map included herein are without prejudice to the status of or sovereignty over any territory, to the delimitation of international frontiers and boundaries and to the name of any territory, city or area. 


\section{Abstract/Résumé \\ New indicators of competition law and policy in 2013 for OECD and non-OECD countries}

This paper presents the new OECD competition law and policies (CLP) indicators which measure the strength and scope of competition regimes in 49 jurisdictions (OECD and non-OECD). The indicators cover areas for which there is a broad consensus among member countries on what constitutes 'good' practice for competition regimes. The results suggest that competition regimes are broadly similar across countries in these areas because most countries have adopted all or a large number of the 'good' policy settings captured by the indicators. On average, the design of competition laws and policies appears to be closer to best practice in OECD countries than in non-OECD countries. Jurisdictions differ relatively more on the enforcement of competition law than on the competition law itself.

\section{JEL classification codes: K21, L4}

Keywords: competition law and policy, indicators

$* * * * * * * * * * * * *$

\section{Nouveaux indicateurs des lois et politiques de la concurrence en 2013 pour les pays de l'OCDE et non-OCDE}

Cet article présente les nouveaux indicateurs des lois et politiques de la concurrence (CLP) de l'OCDE portant sur la solidité et la portée des régimes de concurrence dans 49 juridictions (OCDE et non-OCDE). Les indicateurs couvrent des domaines pour lesquels il existe un large consensus entre les pays membres sur ce qui constitue une «bonne» pratique pour les régimes de concurrence. Les résultats suggèrent que les régimes de concurrence sont globalement similaires dans ces domaines parce que la plupart des pays ont adopté la totalité ou une grande partie des « bonnes » pratiques captées par les indicateurs. En moyenne, la conception des lois et des politiques de la concurrence semble se rapprocher davantage des bonnes pratiques dans les pays de l'OCDE que dans les pays non membres. Les juridictions diffèrent relativement plus sur l'application du droit de la concurrence que sur le droit de la concurrence per se.

\section{JEL classification codes : K21, L4}

Mots-clefs: lois et politiques de la concurrence, indicateurs

You can copy, download or print OECD content for your own use, and you can include excerpts from OECD publications, databases and multimedia products in your own documents, presentations, blogs, websites and teaching materials, provided that suitable acknowledgment of OECD as source and copyright owner is given. All requests for commercial use and translation rights should be submitted to rights@oecd.org. 


\section{TABLE OF CONTENTS}

\section{NEW INDICATORS OF COMPETITION LAW AND POLICY IN 2013 FOR OECD AND NON-OECD

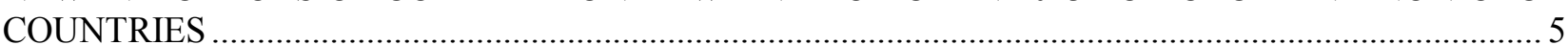

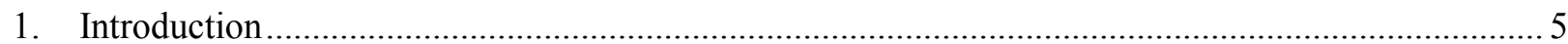

2. Two overlapping sets of indicators to measure the strength and scope of competition law and policy7

3. Competition laws and policies in OECD and selected non-OECD countries ................................ 10

3.1. Cross-country differences in competition laws and policies................................................. 10

3.2. Impact of integrating EU legislation in the indicators for EU and EFTA Member States........ 16

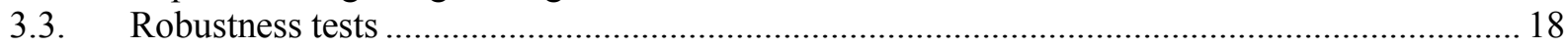

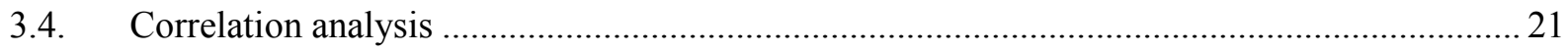

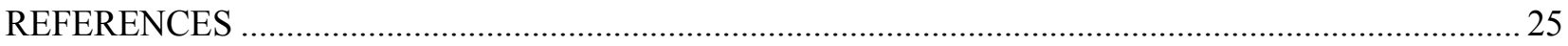

ANNEX A1. DETAILED PRESENTATION OF THE CLP INDICATORS ............................................. 27

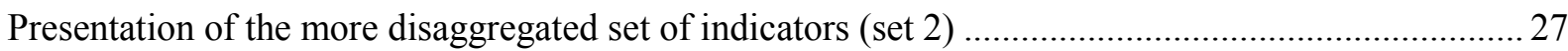

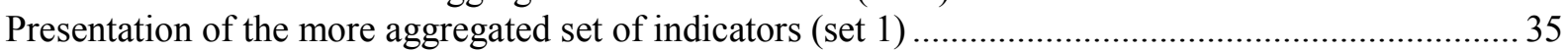

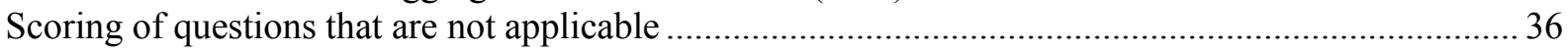

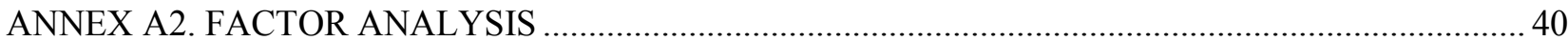

\section{Tables}

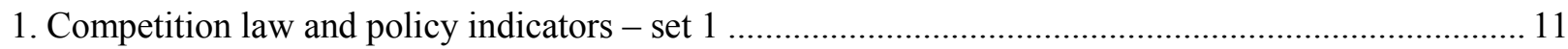

2. National competition laws and policies for EEA countries - set 1 ….......................................... 17

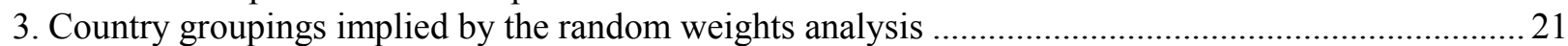

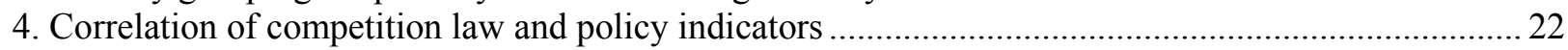

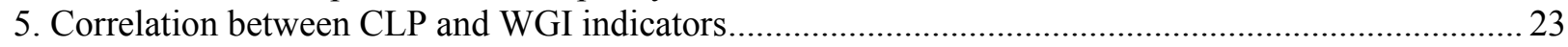

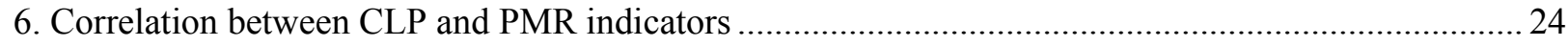

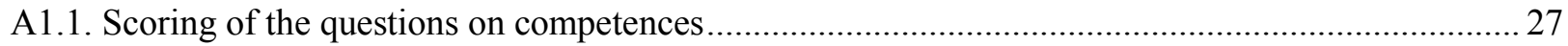

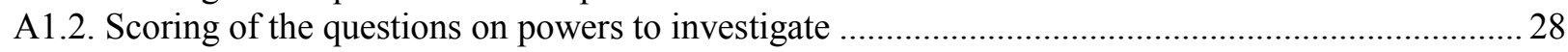

A1.3. Scoring of the questions on powers to sanction and remedy ....................................................... 29

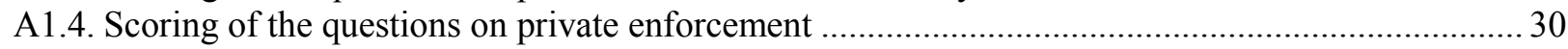

A1.5. Scoring of the questions on horizontal agreements ................................................................... 30

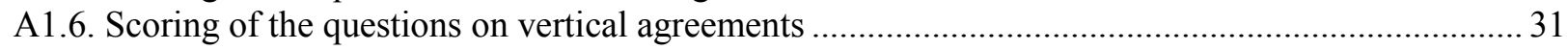

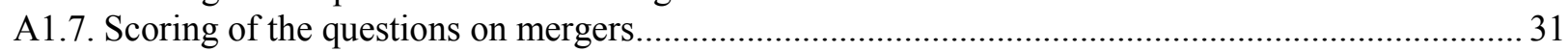

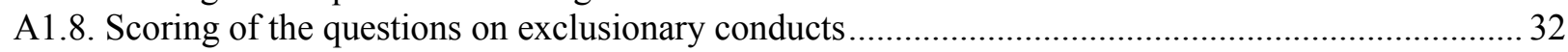

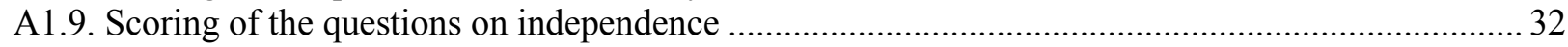

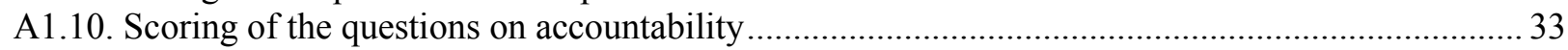

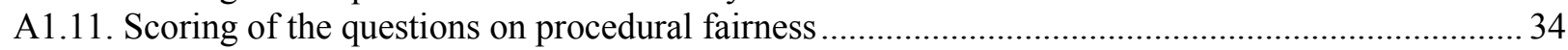

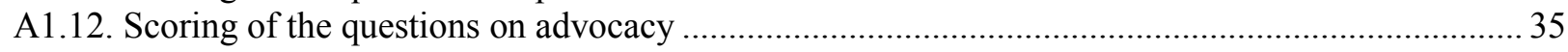

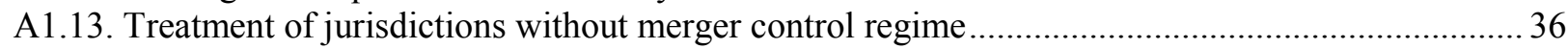

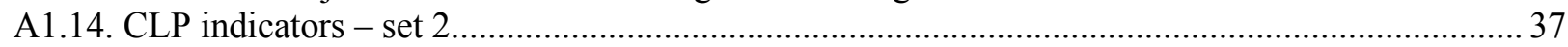

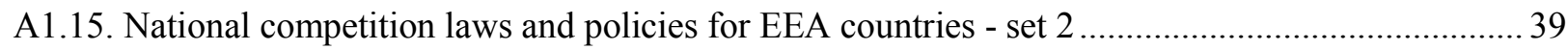

A2.1. Factor extraction for the indicator of scope of action............................................................... 41

A2.2. Loadings and weights obtained for the indicator of scope of action .......................................... 41 


\section{Figures}

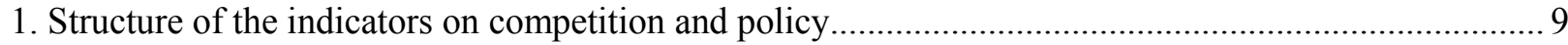

2. Average level of CLP indicators in OECD and non-OECD countries ............................................ 12

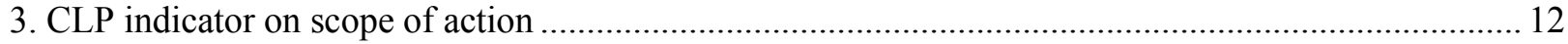

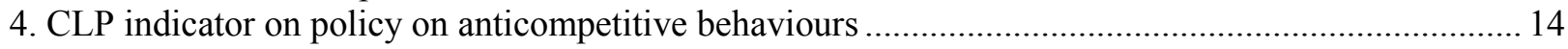

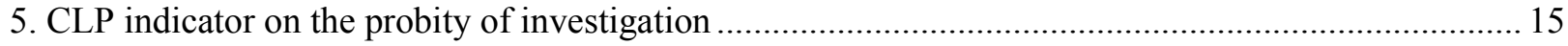

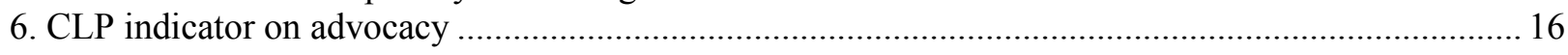

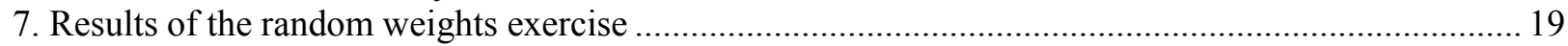

Note: The statistical data for Israel are supplied by and under the responsibility of the relevant Israeli authorities. The use of such data by the OECD is without prejudice to the status of the Golan Heights, East Jerusalem and Israeli settlements in the West Bank under the terms of international law. 
ECO/WKP(2013)96

\title{
NEW INDICATORS OF COMPETITION LAW AND POLICY IN 2013 FOR OECD AND NON- OECD COUNTRIES
}

\author{
Enrico Alemani, Caroline Klein, Isabell Koske, Cristiana Vitale and Isabelle Wanner ${ }^{1}$
}

\section{Introduction}

1. A competitive product market environment that allows new firms to challenge incumbents, efficient firms to grow, and inefficient ones to exit, can help boost economic growth and living standards. ${ }^{2}$ Two main policy ingredients are necessary for a growth-enhancing competition environment. First, product market regulation (PMR) should be set in a way that does not hamper competition (Conway et al., 2005). Second, anticompetitive behaviours that hinder the functioning of markets should be prohibited and punished within an effective antitrust framework; and mergers that may reduce competition should be blocked or at least remedied. The OECD has developed indicators of product market regulation (Wölfl et al., 2009 and 2010, Koske et al., 2013), but until recently did not have indicators to characterise competition regimes.

2. This paper presents the new OECD competition law and policy (CLP) indicators which measure the strength and scope of competition regimes in 34 OECD and 15 non-OECD jurisdictions. ${ }^{3}$ Computing CLP indicators is a prerequisite for assessing the impact of competition regimes on economic performances and will allow for a better integration of competition law and policy in economic analysis based on policy indicators, such as Going for Growth. ${ }^{4}$ For instance, using several indicators summarising

1. Enrico Alemani and Cristiana Vitale are members of the OECD Directorate for Financial and Enterprise Affairs. Caroline Klein, Isabell Koske, and Isabelle Wanner are members of the OECD Economics Department. They would like to thank Jørgen Elmeskov, Jean-Luc Schneider, John Davies, Alain de Serres, Romain Duval, Pier Carlo Padoan, Giuseppe Nicoletti, Jeremy West, Joao Azevedo, Yunhee Kim, Lorenzo Ciari, Antoine Goujard, and Zsofia Tari for their helpful comments and suggestions, as well as Caroline Abettan and Celia Rutkoski for excellent technical support. The opinions expressed in this paper are the authors' and do not necessarily correspond to those of the OECD or its member countries.

2. A number of empirical studies find a positive link between competition and productivity growth (see for instance Nickell, 1996; Disney et al., 2000). Other studies focus on the direct link between regulatory measures and productivity and show that regulation which improves the functioning of markets positively affects economic performance (Conway et al., 2006; Nicoletti and Scarpetta, 2003). See Ahn (2002) for a general review of the empirical and theoretical literature on the link between competition and economic outcomes and Nicodème and Saumer-Leroy (2007) for the link between product market reforms and productivity.

3. Høj (2007) computed a set of indicators on competition law and policies for OECD countries and the BRIICS. Non-OECD jurisdictions covered in the analysis are Brazil, Bulgaria, Colombia, Egypt, the European Union, India, Indonesia, Latvia, Lithuania, Malta, Peru, Romania, Russia, Ukraine and South Africa.

4. The separate influence of competition law and policy is currently not reflected in the Going for Growth exercise. Going for Growth defines five priorities for structural policies in OECD countries, the BRIICS and European Union. Three of these priorities are identified based on internationally comparable OECD indicators of policy settings and performance. The other two draw on country specific expertise but are often supported by indicator-based evidence. Details on the selection of policy priorities are provided in Annex 1.A1 of OECD (2013). 
key institutional and enforcement features of competition regimes, Buccirossi et al. (2013) find an empirical link between competition policy and total factor productivity growth. The CLP indicators will also allow for cross-country descriptions of certain basic features of the competition regime and the monitoring of change on these features over time, thereby providing valuable information for the conduct of OECD country reviews of economic performance and structural policy reforms.

3. Two overlapping sets of CLP indicators are constructed from the same database, a first (more aggregated) one that includes four indicators and a second (more disaggregated) one that covers twelve indicators. The indicators are set to assess the ability of a country's competition regime to achieve more competition while allowing efficiency gains. They cover areas for which there is a broad consensus on what constitutes a 'good' policy setting in that respect. In the first - more aggregated - indicator set, three of the four indicators measure the effectiveness of competition regimes and cover the following areas: $(i)$ scope of action (the legal powers to investigate and impose sanctions on antitrust infringements and to investigate, remedy, or block mergers); (ii) policy on anticompetitive behaviours (approaches toward the assessment of horizontal and vertical agreements, exclusionary conducts and mergers as well as effective action taken against anticompetitive behaviours); (iii) probity of investigation (independence and accountability of the institutions enforcing the competition law as well as their procedural fairness). The fourth indicator captures competition advocacy, i.e. activities promoting competition by other means than standard enforcement of the competition law, such as the review of regulation that might have an impact on competition. The second (more disaggregated) indicator set covers the same topics, but breaks them down into more specific policy areas. In both cases, the indicators capture both de jure and de facto information.

4. The CLP indicators are by nature an imperfect reflection of complex policy settings. They do not describe all individual aspects of competition regimes, since they try to capture features that are common to all regimes, and ignore possible interactions across different dimensions of competition policy. ${ }^{5}$ In addition, restricting the indicators to policy dimensions for which there is a broad agreement among member countries as to what constitutes best practice has the downside that dimensions whose effects are more controversial, but that might still matter for growth, are left out from the dataset. This reduces the variability in the dataset and, to the extent that the omitted dimensions are important for growth, may make it more difficult to empirically establish a link with economic outcomes. ${ }^{6}$ Finally, the indicators may be sensitive to the methodology used to aggregate detailed information. ${ }^{7}$

5. Consequently, the indicators should be seen as providing an approximate indication of the overall strength and scope of a competition policy regime, rather than a complete and detailed representation of its characteristics, and as such they should be interpreted with caution. Despite these limitations the indicators can be a useful tool for policy makers and practitioners. Simplifying and quantifying information provides comparable measures of various dimensions of competition law and policy, thereby contributing to international dialogue, transparency, accountability, and, ultimately, improvements in policy settings.

6. The following conclusions emerge from an analysis of the indicators:

5. The indicators do not cover specific policy features that are present only in one or a few regimes. For instance, competition tools, such as market investigations, used in the United Kingdom are not captured by the indicators.

6. For instance, the human and financial resources of the competition agency, the length of procedures, and the level of sanctions are not included in these indicators.

7. This caveat is addressed by carrying out sensitivity analysis. 
- The results suggest that competition regimes are broadly similar across countries in the policy areas covered by the analysis because most countries have adopted all or a large number of the 'good' policy settings captured by the indicators. Differences across jurisdiction materialize in a limited number of questions. On average, though, the design of competition laws and policies appears to be closer to best practice in OECD countries than in non-OECD countries.

- Jurisdictions differ relatively more on the enforcement of competition law than on the law itself. Differences are larger for the indicators assessing the probity of investigation and competition advocacy than for those covering the scope of action and the policies on anticompetitive behaviours.

- Regarding the probity of investigation, the main differences across countries relate to the provision of guidelines by competition agencies.

- As regards advocacy, the obligation for the government to reply to the recommendations made in market studies and the competition assessment of new regulation are the main sources of divergences.

- The indicators are sensitive to the choice of weighting scheme used for aggregating detailed information. Nevertheless, groups of countries with statistically different outcomes can still be identified.

7. The remainder of this paper is structured as follows: Section 2 discusses the data collection process and the design of the indicators and Section 3 presents the indicator values. Section 3 also discusses the results of two statistical tests performed to assess the robustness of the indicators values to the weighting scheme used to aggregate information. It also presents a first analysis of the correlation between the CLP indicators and other policy indicators, including the 2013 PMR indicators. ${ }^{8}$

\section{Two overlapping sets of indicators to measure the strength and scope of competition law and policy}

8. The indicators are constructed for all OECD and selected non-OECD jurisdictions (49 jurisdictions in total) and refer to the year 2013. ${ }^{9}$ They are based on answers provided by the jurisdictions' competition authorities to a questionnaire on competition law and policies that was circulated in the spring of 2013. The coverage rate of the resulting database is equal to $100 \%{ }^{10}$

9. A score is assigned to each possible answer to the questions included in the questionnaire. The scores vary on a $0-6$ scale (from the most to the least effective competition regime). This is the same approach used by the OECD for the PMR indicators. They assess whether competition policy features are effectively preventing anticompetitive behaviours that harm productivity growth (i.e. exclusionary conducts, and anticompetitive horizontal and vertical agreements), blocking anticompetitive mergers and removing barriers to competition. The indicators are computed based on binary information which limits the number of assumptions that need to be made when scoring the observations. Each data point refers to a

8. This analysis is set to be complemented by further empirical analysis to explore the effects of different competition law and policy settings on economic performance.

9. They reflect the situation on $1^{\text {st }}$ January 2013. Recent reforms implemented over the year are not taken into account.

10. Some questions were not applicable for some jurisdiction because they relate to policies that are not in place in these countries. The scoring of these questions is detailed in Annex A1. 
particular feature of the competition regime and assesses whether it is conducive to higher efficiency or not. ${ }^{11}$ The indicators are constructed based on a simple weighting system to ease the use and interpretation of the results.

10. In the European Economic Area (EEA, i.e. the European Union member states plus Norway, Iceland and Lichtenstein), both national and European institutions have complementary competence to enforce competition law. The European competition law is enforced by the national competition authorities, the European Commission, and the EFTA Surveillance Authority (for Norway, Iceland, and Liechtenstein). ${ }^{12}$ Thus, for EU Member States, Norway, and Iceland, the CLP indicators should reflect the features of the national competition regime, but also incorporate information on the EEA competition regime. The option retained here is to compute the simple average of national and EEA scores, following Buccirossi et al. (2011). ${ }^{13}$ For purpose of comparison, the CLP indicators are also calculated by only considering country-specific scores. Besides, when a jurisdiction has two competition agencies (as in the United States and the United Kingdom), its CLP indicators include the relevant information on both institutions. $^{14}$

11. Two sets of indicators are computed, each reflecting a different way of aggregating the data (Figure 1). For the first (more aggregated) indicator set, the information collected from the questionnaire is regrouped in 4 indicators: 'scope of action', 'policy on anticompetitive behaviours', 'probity of investigation', and 'advocacy' (set 1 in Figure 1). For the second (more disaggregated) indicator set, the information is regrouped into twelve indicators capturing more specific features of competition law and policy: 'competences', 'powers to investigate', 'powers to sanction and remedy', 'private enforcement', 'policy on horizontal agreements', 'policy on vertical agreements', 'policy on mergers', 'policy on exclusionary conducts', 'independence', 'accountability', 'procedural fairness', 'advocacy' (set 2 in Figure 1). ${ }^{15}$ Each of the four components of the first set covers several specific components of the second set, as illustrated in Figure 1 (dotted lines).

12. Each individual indicator in the two sets is constructed by aggregating raw information using equal weights (i.e. if an indicator is based on seven questions, each of the questions is given a weight of one-seventh). This means that each question has the same importance for the construction of the indicator. This aggregation method implies that the four indicators of the first set are not a simple average of the

11. Scoring continuous information requires assumptions about ranges and thresholds in the scoring system, which is avoided in the new indicator set.

12. A number of rules regulate the collaboration between the European Commission, the EFTA Surveillance Authority and the national competition authorities (European Commission, 2004). For instance, the Commission examines mergers that have a Community dimension, the latter being defined based on criteria relative to the turnover of the companies involved.

13. While ideally the weights should reflect the relative importance of the EEA competition regime for the various Member States, measuring this in practice is not straightforward and hence for reasons of simplicity and transparency, the choice was made to apply equal weights.

14. The questionnaire was sent to all competition agencies within a jurisdiction. When a jurisdiction has two competition agencies and the question applies to both of them, the score is an average of the two answers. When a question is applicable to only one of the agencies, because only one agency has competences in the area covered by the question, only the score of this agency is considered.

15. Both indicator sets are described in detail in Annex A1. 
indicators of the second set. ${ }^{16}$ While the choice of equal weights is ultimately arbitrary, it has the virtue of simplicity and transparency.

Figure 1. Two overlapping sets of indicators on competition and policy

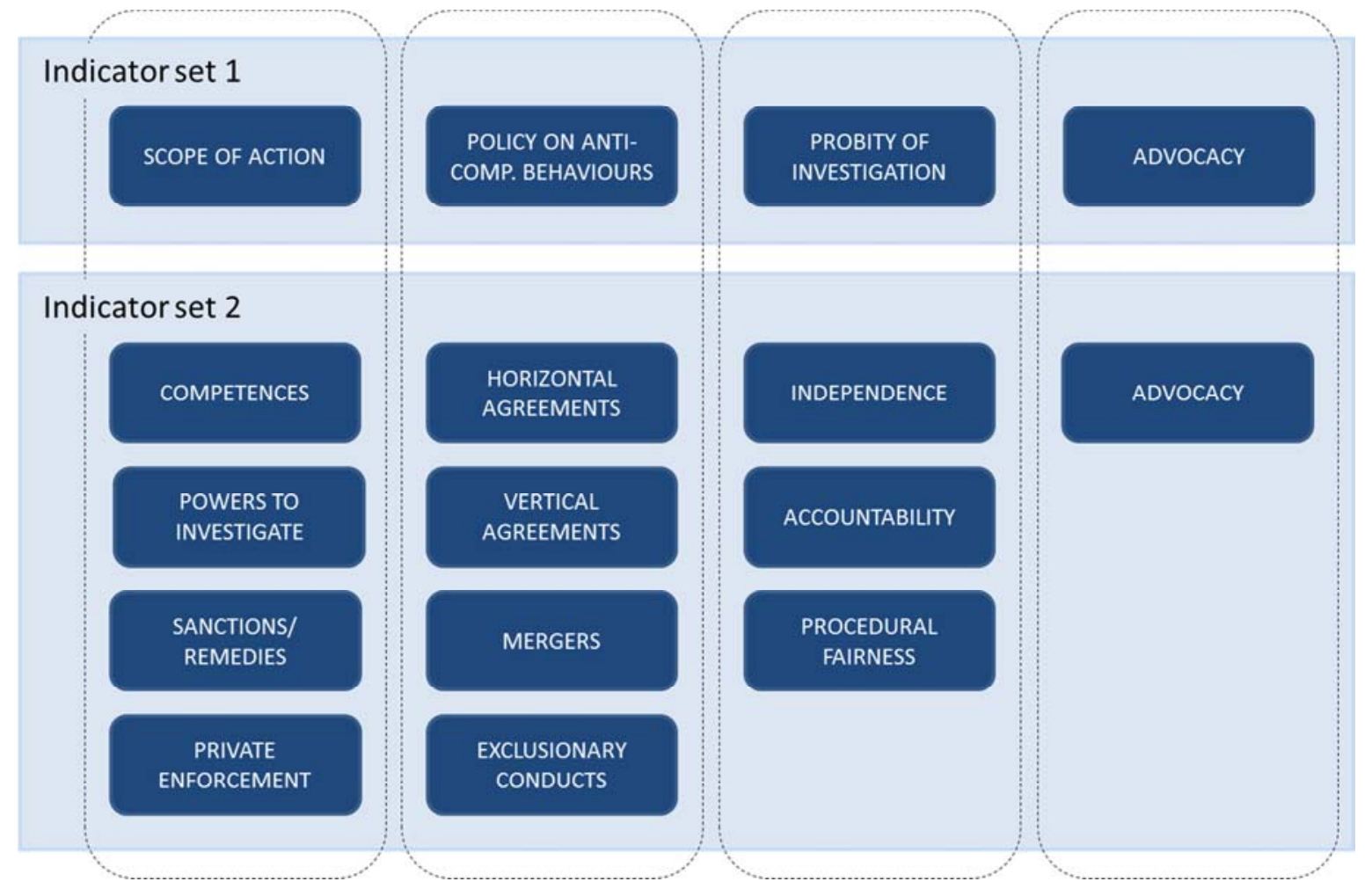

13. More specifically, the four components of the more aggregated indicator set cover the following features of competition regimes:

- Scope of action: The effectiveness of a competition regime depends on the scope of the activities it can undertake to deter, discover, stop and punish anticompetitive behaviours and mergers. These are measured by the extent of exemptions from the competition law for public and foreign firms, the powers of the institutions enforcing the competition law to investigate and to impose sanctions on competition law infringements and to investigate and remedy or block anticompetitive mergers, and the possibility for individuals, firms or group of consumers to take legal action against firms whose actions have caused them economic or financial harm.

- Policy on anticompetitive behaviours: An effective competition law and policy regime is one where anticompetitive behaviours and mergers that result in welfare and productivity losses are punished or blocked. This requires that during the investigation of an allegedly antitrust infringement or of a merger, the economic impact of each case is assessed and potential efficiencies generated are taken into account. The 'policy on anticompetitive behaviours' indicator assesses whether anticompetitive behaviours and anticompetitive mergers are prohibited

16. For example, the indicator 'scope of action' from the first set is constructed as the simple average of the 21 questions that are used in the indicators 'competences' (2 questions), 'powers to investigate' (6 questions), 'powers to sanction and remedy' (10 questions), and 'private enforcement'(3 questions) from the second set and is not the average of these four indicators. 
in the jurisdiction and what factors are considered when assessing them. It also captures whether in the last five years there have been interventions against such behaviours and mergers (e.g. by blocking an anticompetitive merger, or by imposing sanctions on a firm for its exclusionary conduct).

- Probity of investigation: The degree of probity of an investigation measures the quality, soundness and transparency of competition law enforcement. It is measured here in terms of three main sub-components: the independence of the institutions enforcing competition law (i.e. whether governments interfere with the investigations or the decisions taken on antitrust infringements and mergers); the fairness of the procedure (i.e. the right of investigated firms to be heard and to receive information on the procedures); and the accountability of the competition regime (i.e. whether the activities and the decisions of the agency are transparent and could be appealed to in court).

- Advocacy: This indicator captures the capacity of the competition regime to advocate for a more competitive environment at different government levels, by reviewing new regulation for its impact on competition, and performing market studies that deliver recommendations on how to foster competition.

\section{Competition laws and policies in OECD and selected non-OECD countries}

\subsection{Cross-country differences in competition laws and policies}

14. This section presents the main results for the more aggregated indicator set. ${ }^{17}$ The results indicate that, in January 2013, competition regimes were broadly similar across countries in the policy areas covered by the indicators. The CLP indicators can potentially vary from 0 to 6 , but most jurisdictions covered are scored between 0 and 2 (Table 1). This is because most competition regimes have adopted all or a large number of the 'good' policy settings captured by the indicators. One should note that the indicators do not perfectly reflect the complexity of these policy settings. They are based on a questionnaire whose format inevitably imposes a limited range of nuances. As a result, similar indicators values can hide important differences across competition regimes. Also, cross-country differences are often driven by a few data points. Nevertheless, the variability of the indicators is not particularly low compared to other OECD policy indicators. ${ }^{18}$ On average, the results suggest that OECD countries have competition policy regimes that are closer to best practice than non-OECD countries (Figure 2).

17. Results for the more disaggregated indicator set can be found in Table A1.1 in Annex 1.

18. For OECD countries, the indicators of 'policy on anticompetitive behaviours' and 'probity of investigation' show a degree of variability similar to that of the overall PMR indicator or the FDI restrictiveness index. The indicator of 'scope of action' shows less variability, while the indicator of 'advocacy' has a larger variance, but this is mainly driven by one outlier. 
Table 1. Competition law and policy indicators - set 1

0 to 6 from the most to the least conductive to competition

\begin{tabular}{|c|c|c|c|c|}
\hline & Scope of action & $\begin{array}{c}\text { Policy on } \\
\text { anticomp. behav. }\end{array}$ & $\begin{array}{c}\text { Probity of } \\
\text { investigation }\end{array}$ & Advocacy \\
\hline Australia & 0.29 & 0.00 & 0.15 & 0.43 \\
\hline Austria & 0.14 & 0.00 & 0.90 & 0.86 \\
\hline Belgium & 0.14 & 0.00 & 0.00 & 0.64 \\
\hline Brazil & 0.00 & 0.00 & 0.30 & 1.29 \\
\hline Bulgaria & 0.00 & 0.32 & 0.00 & 0.86 \\
\hline Canada & 0.43 & 0.63 & 0.60 & 1.71 \\
\hline Chile & 0.43 & 0.32 & 1.20 & 1.71 \\
\hline Colombia & 0.00 & 0.32 & 1.20 & 1.71 \\
\hline Czech Republic & 0.14 & 0.00 & 0.00 & 0.43 \\
\hline Denmark & 0.29 & 0.00 & 0.00 & 0.21 \\
\hline Egypt & 2.29 & 2.21 & 2.57 & 1.71 \\
\hline Estonia & 0.14 & 0.00 & 0.90 & 0.64 \\
\hline Finland & 0.29 & 0.16 & 0.15 & 0.64 \\
\hline France & 0.00 & 0.00 & 0.00 & 0.64 \\
\hline Germany & 0.00 & 0.00 & 0.30 & 0.86 \\
\hline Greece & 0.14 & 0.16 & 0.00 & 0.64 \\
\hline Hungary & 0.00 & 0.16 & 0.60 & 0.64 \\
\hline Iceland & 0.07 & 0.16 & 0.15 & 1.61 \\
\hline India & 0.86 & 0.95 & 0.30 & 1.29 \\
\hline Indonesia & 1.71 & 0.95 & 0.00 & 1.71 \\
\hline Ireland & 0.29 & 0.32 & 0.15 & 0.43 \\
\hline Israel & 0.00 & 0.32 & 1.05 & 4.29 \\
\hline Italy & 0.14 & 0.16 & 0.00 & 0.64 \\
\hline Japan & 0.57 & 1.58 & 0.00 & 0.86 \\
\hline Korea & 0.57 & 0.00 & 0.00 & 0.43 \\
\hline Latvia & 0.29 & 0.00 & 0.75 & 0.64 \\
\hline Lithuania & 0.14 & 0.00 & 0.45 & 0.86 \\
\hline Luxembourg & 1.00 & 0.63 & 0.60 & 1.71 \\
\hline Malta & 0.29 & 0.63 & 0.15 & 1.07 \\
\hline Mexico & 0.00 & 0.32 & 0.30 & 1.29 \\
\hline Netherlands & 0.29 & 0.32 & 0.15 & 0.64 \\
\hline New Zealand & 0.29 & 0.00 & 0.00 & 0.43 \\
\hline Norway & 0.36 & 0.47 & 0.45 & 0.75 \\
\hline Peru & 0.29 & 0.32 & 1.80 & 0.86 \\
\hline Poland & 0.14 & 0.00 & 0.45 & 0.64 \\
\hline Portugal & 0.14 & 0.00 & 0.00 & 0.86 \\
\hline Romania & 0.00 & 0.00 & 0.15 & 0.64 \\
\hline Russia & 0.29 & 0.00 & 0.30 & 0.00 \\
\hline Slovakia & 0.00 & 0.32 & 0.45 & 1.07 \\
\hline Slovenia & 0.29 & 0.16 & 0.90 & 0.64 \\
\hline South Africa & 1.14 & 0.32 & 1.50 & 0.86 \\
\hline Spain & 0.00 & 0.00 & 0.08 & 0.43 \\
\hline Sweden & 0.29 & 0.00 & 0.60 & 0.86 \\
\hline Switzerland & 0.29 & 0.00 & 1.20 & 0.43 \\
\hline Turkey & 0.29 & 0.00 & 0.00 & 0.86 \\
\hline Ukraine & 0.29 & 0.95 & 1.80 & 0.43 \\
\hline United Kingdom & 0.29 & 0.00 & 0.08 & 0.21 \\
\hline United States & 0.43 & 0.00 & 0.75 & 1.29 \\
\hline OECD & 0.24 & 0.18 & 0.36 & 0.89 \\
\hline
\end{tabular}

Source: OECD calculations.

Note: For EEA Member States, the indicators reflect both national and EEA competition law and policy. 
Figure 2. Average level of CLP indicators in OECD and non-OECD countries

0 to 6 from most to least conductive to competition

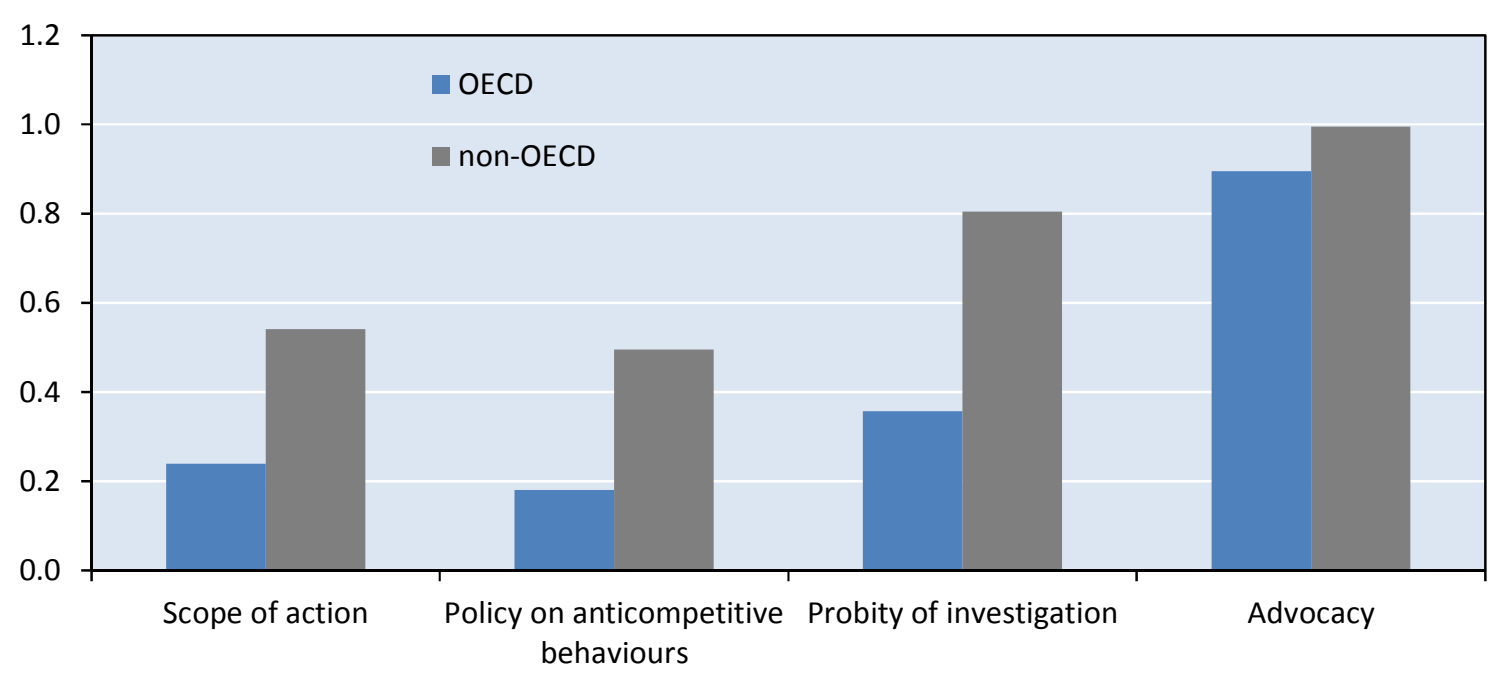

Source: OECD calculations.

\subsubsection{Scope of action}

15. This indicator covers three main features of competition law and policy: $i$ ) the absence of exemptions from the competition law for public and foreign firms, ii) the powers of the institutions enforcing the competition law to investigate and impose sanctions on antitrust infringements and to remedy or block anticompetitive mergers, and iii) the extent of private enforcement. There are only minor differences in the scope of action against anticompetitive behaviours for most of the countries covered. The indicator varies between 0 and 1 for all countries but three (Figure 3).

Figure 3. CLP indicator on scope of action

0 - 6 from the most to the least conductive to competition

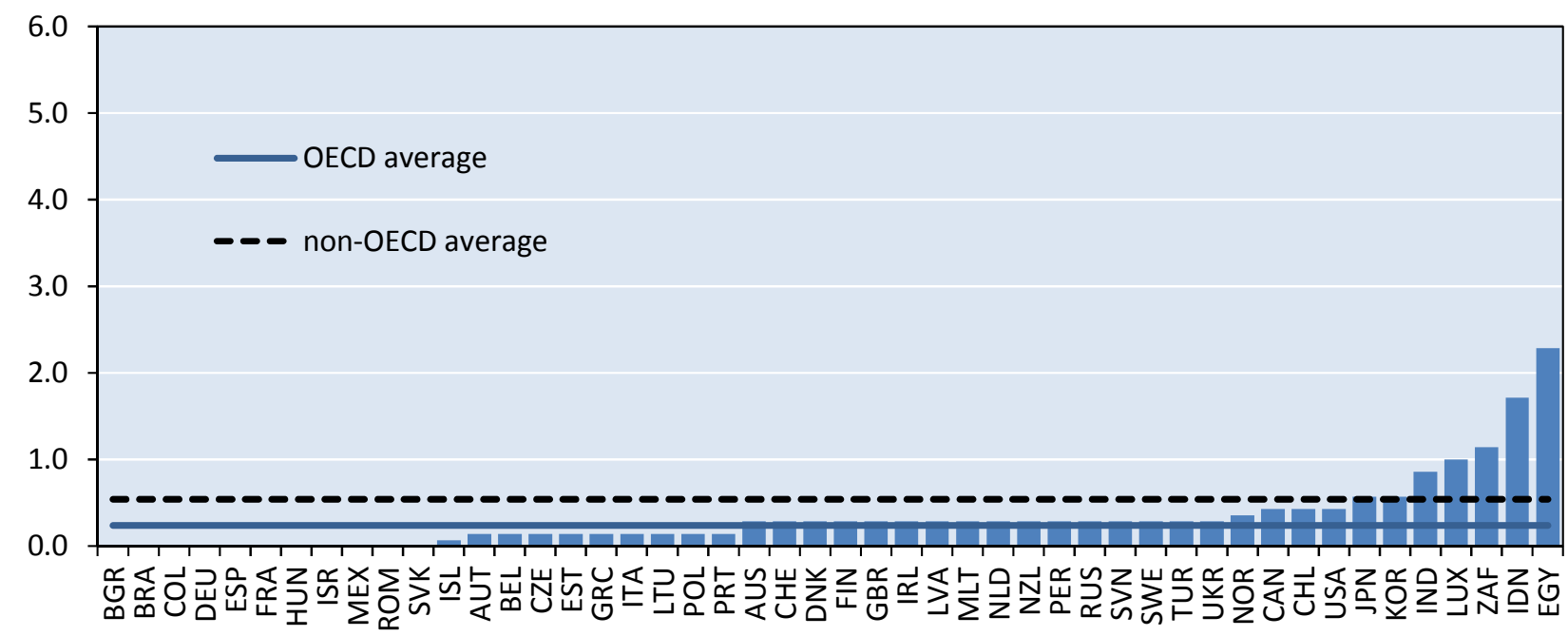

Source: OECD calculations.

Note: Countries with the same score are ranked by alphabetical order (for instance, the indicator value is the same for Bulgaria and Romania). 
16. In all jurisdictions, but Indonesia, competition law applies to firms located outside the jurisdiction whose behaviour directly affects competition or consumers in domestic markets. ${ }^{19}$ In most countries, state-controlled firms are exempt from the application of competition law in some sectors or for some antitrust infringements.

17. The powers to investigate and to sanction captured by the indicator are quite similar across jurisdictions. ${ }^{20}$

- Egypt and Luxembourg stand out because they do not have a merger control regime and their competition agencies (or courts) have thus less power to impose sanctions and remedies on anticompetitive behaviours.

- All jurisdictions can compel firms and third parties to provide information to help an investigation on antitrust infringements. Likewise, in almost all countries that control mergers, institutions enforcing competition law can oblige third parties to provide information to help an investigation on mergers (the only exception being South Africa). ${ }^{21}$ With the exception of Indonesia, all jurisdictions have the right to perform unannounced investigations and only four jurisdictions have not used this power over the past five years (India, Luxembourg, Malta, and New Zealand). ${ }^{22}$ All jurisdictions except Sweden can impose sanctions on firms that hinder an investigation and around two thirds of the jurisdictions have done so over the past ten years. ${ }^{23}$

- In all jurisdictions remedies and sanctions can be imposed on firms that have committed an antitrust infringement or do not comply with the remedies imposed. ${ }^{24}$ All jurisdictions that have a merger control regime can impose or accept remedies to clear a merger. In more than $80 \%$ of the jurisdictions interim measures can be imposed if there is a concern that the alleged antitrust infringement may lead to irreversible damages. In most jurisdictions, the legal procedures can be shortened by settling voluntarily with the parties investigated or by accepting remedies at an early stage in the latter.

19. Competition law could apply to international cartels or mergers outside the jurisdiction that affects local consumers. For instance, a merger outside South Africa may have to be notified and approved if the parties' sales or assets in South Africa exceed the notification thresholds.

20. $80 \%$ of countries score 0 for the indicator 'powers to investigate' and $90 \%$ score less than 1 for the indicator 'powers to sanction'.

21. In the United Kingdom, only the Competition Commission is allowed to compel firms and third parties to provide information.

22. In the United States, the Fair Trade Commission cannot perform unannounced investigations, but the Department of Justice can.

23. Sanction is a broad term that includes fines and other forms of penalties aimed at ensuring compliance with the law. Sanctions can be criminal (such as imprisonment) and non-criminal (such as fines) and can be imposed on firms and/or individuals. The indicator does not measure whether jurisdictions can impose sanctions on individuals nor does it make a distinction between financial and criminal sanctions since there was no agreement among member countries as to what constitutes best practice in this policy domain. The fact that no sanction has been imposed on a given time period is difficult to interpret. The absence of sanction could be due to the absence of infraction.

24. Remedies are measures that aim at eliminating competition problems. For instance, competition agencies use remedies in merger cases to eliminate the risks that a given transaction may pose to competition. Such remedies include for example the sale of a part of activity, the transfer or licensing of intellectual property rights, transparency provisions, or contracting limitations. 
18. All countries have provisions that allow individuals and firms to bring legal actions to seek damages from firms that have committed an antitrust infringement. More than two thirds of the jurisdictions also offer this opportunity to groups of consumers.

\subsubsection{Policy on anticompetitive behaviours}

19. This indicator collects information on whether anticompetitive behaviours and mergers are punished or blocked, what factors are considered when assessing them, and whether in the last five years there have been interventions against such behaviours and mergers. As in the case of the indicator of 'scope of action', the indicator of 'policy on anticompetitive behaviours' shows few differences across countries (Figure 4). These differences are mainly driven by the de facto questions asking whether at least one anticompetitive behaviour has been punished and one merger has been blocked or remedied in the past five years. ${ }^{25}$

20. All jurisdictions prohibit anticompetitive exclusionary conducts by dominant firms, as well as anticompetitive horizontal and vertical agreements. During the investigation phase, carrying out an economic analysis helps to determine whether a conduct is likely to raise competition concerns but also to identify efficiency gains it may generate. For instance, some antitrust behaviours and some mergers may negatively affect competition but also bring economic benefits to consumers that outweigh the former (e.g. economies of scale, reductions in transaction costs). Only a detailed economic analysis can identify these effects (OECD, 2012). Two jurisdictions (Japan and Slovakia) do not conduct economic analyses and four jurisdictions (Canada, Egypt, Hungary and Ukraine) do not consider potential efficiencies when investigating certain antitrust infringements.

Figure 4. CLP indicator of policy on anticompetitive behaviours

0-6 from most to least conductive to competition

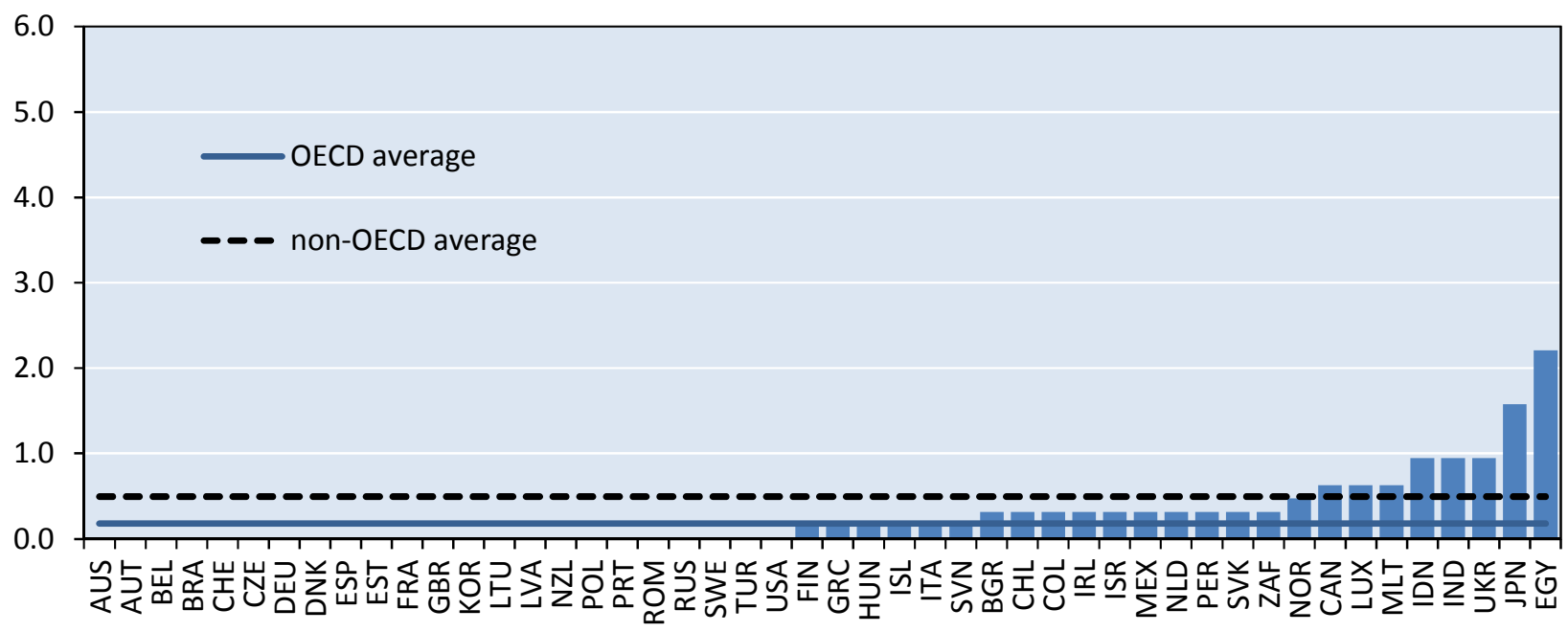

Source: OECD calculations

21. As regards enforcement, almost two thirds of the jurisdictions have imposed sanctions or remedies on at least one anticompetitive horizontal agreement other than a cartel, one anticompetitive

25. The fact that action has been taken over the past five years imperfectly reflects the capacity of the competition authorities to hamper anticompetitive behaviours, in particular for small jurisdictions in which the number of antitrust infringements might be relatively low compared to the average. 
vertical agreement and one exclusionary conduct over the past five years. A well-designed leniency programme - i.e. a programme that encourages companies involved in a cartel to actively cooperate with the enforcement authorities against a full or partial immunity from sanctions - is a key instrument for destabilising cartels (OECD, 2002). All jurisdictions, but Malta and Indonesia, have a leniency programme for cartel participants and all but Bulgaria, Egypt, India, and Ukraine have received at least one application in the last five years. Among the countries that control mergers, only five have not blocked a merger or cleared it with remedies over the past five years (Bulgaria, India, Indonesia, Malta, and Peru).

\subsubsection{Probity of investigation}

22. This indicator measures the independence of the bodies enforcing competition law, the fairness of the investigative procedure, and the accountability of the institutions enforcing competition law. The indicator of probity of investigation also shows a pretty strong degree of homogeneity across countries (Figure 5). Most countries appear to have adopted practices that promote transparency, independence and accountability in the enforcement of competition law. Government interventions in investigations and decisions on antitrust cases and mergers have happened in only four jurisdictions over the past five years (Germany, the United Kingdom, Spain and Hungary). All competition agencies publish a report on their activities. In most jurisdictions all the decisions that ascertain the existence of an antitrust infringement and all the decisions that block a merger or clear it with remedies are published. ${ }^{26}$ In all jurisdictions, but Austria, all decisions on antitrust matters can be appealed in court with respect to their substance. In all jurisdictions, except Ukraine, parties investigated for an antitrust infringement or a merger can consult the competition agency to receive additional information on the procedure. Parties also have the right to be heard and present arguments for their defence in most jurisdictions (the exceptions being Egypt for antitrust infringement and Finland for mergers).

Figure 5. CLP indicator on the probity of investigation

0 to 6 from most to least conductive to competition

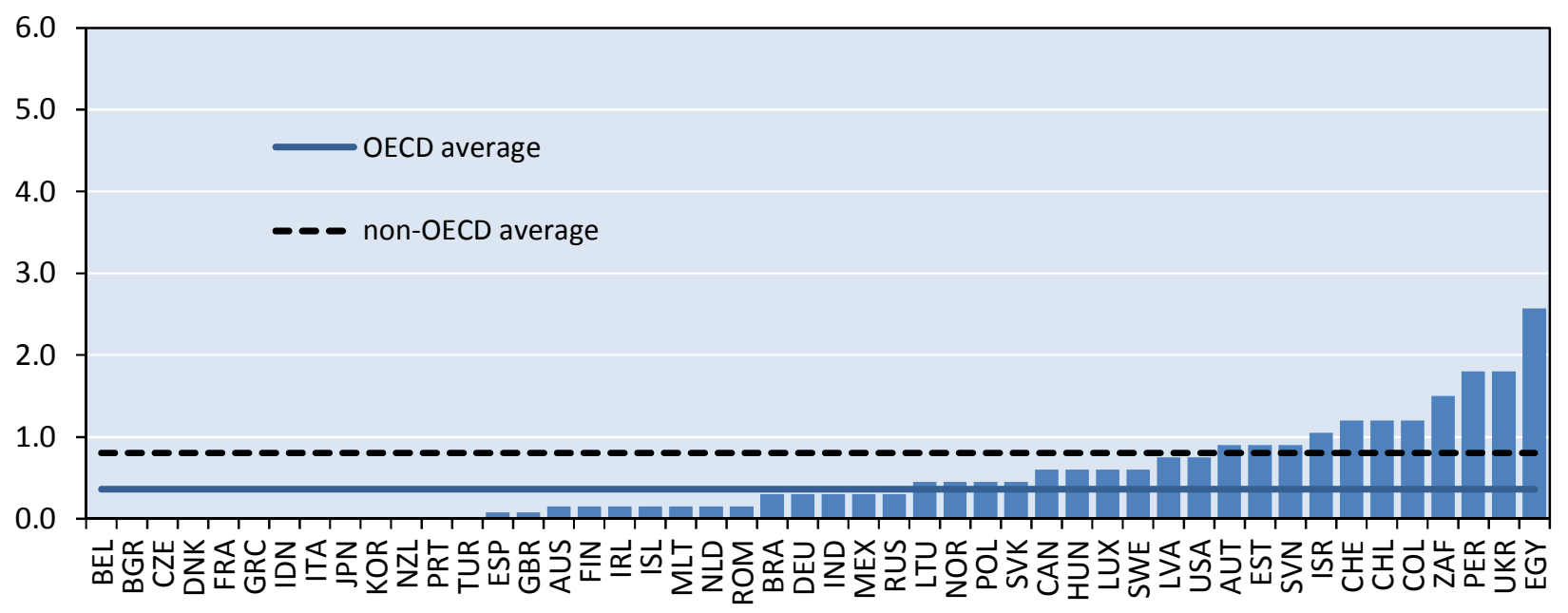

Source: OECD calculations

23. The main differences across countries lie in the answers to the questions on the publication of guidelines by competition agencies. Publishing guidelines is important practice for an effective enforcement of competition law, as it contributes to the deterrence effect by clarifying the law and

26. Australia and Israel do not publish all decisions on mergers. The Netherlands and Ukraine do not publish all decisions on both mergers and antitrust infringements. 
informing firms on the risks and consequences of breaking it (OECD, 2007). While around $80 \%$ of the agencies publish guidelines on the investigative procedure and on how mergers are assessed, only around $60 \%$ do so for the assessment of abuses of dominance, horizontal and vertical agreements and for the setting of monetary sanctions.

\subsubsection{Advocacy}

24. Competition advocacy is quite widespread among the countries covered by the indicators (Figure 6). All competition regimes advocate competition at the central government level. Most of them also do so at the local level (Luxembourg and Colombia being the only exception). In all jurisdictions, except Israel, it is possible to conduct market studies that lead to recommendations on how to remove barriers to competition. All of those jurisdictions, but Luxembourg, have performed at least one market study in the past five years.

Figure 6. CLP indicator on advocacy

0 to 6 from most to least conductive to competition

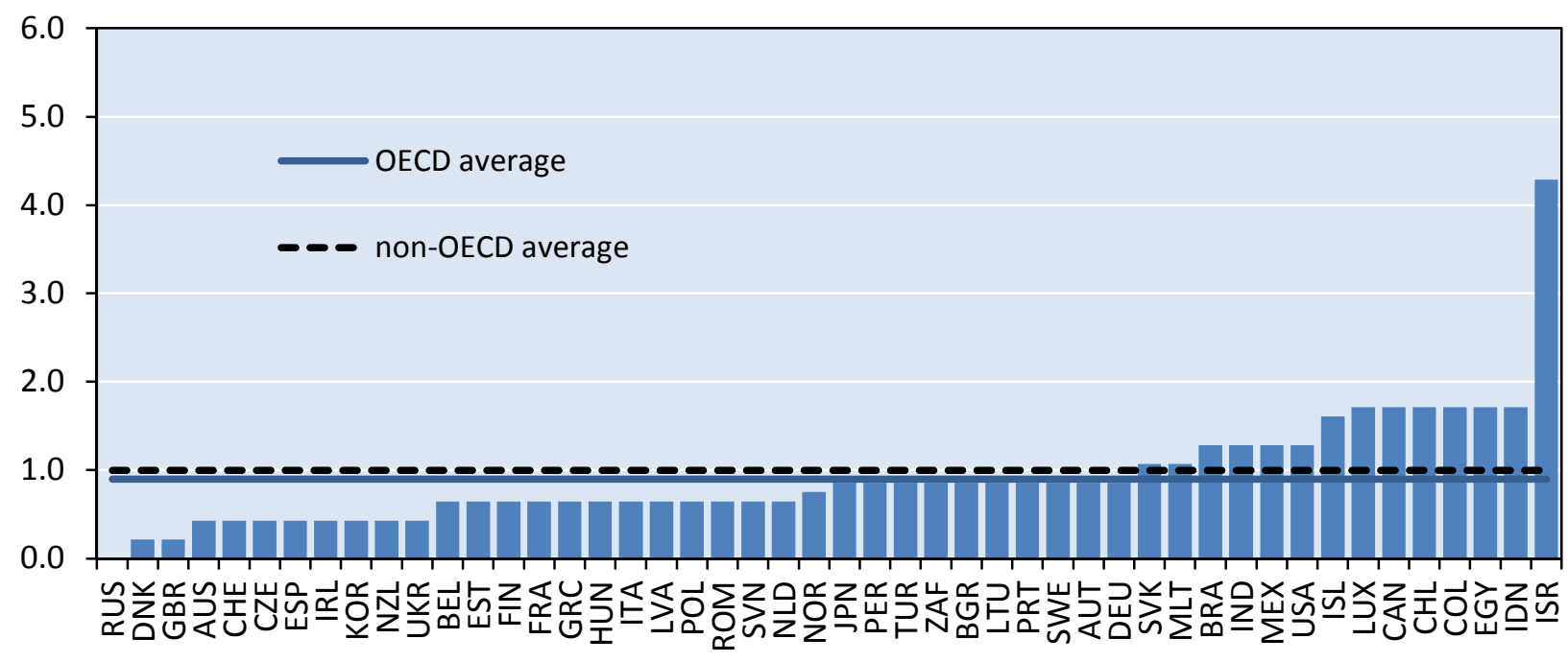

Source: OECD calculations

25. Nevertheless, room for improvement exists for competition advocacy. In most jurisdictions the government does not have to reply to the recommendations included in market studies. There is an obligation to respond only in Denmark, the United Kingdom, Ireland, Norway, and Russia. Among the governments which are not required to provide a response, less than one third usually does so in practice. Besides, in more than half of the jurisdictions, not all new regulations that may have an impact on competition are subject to a competition assessment. And in eight jurisdictions, no regulation is subject to a competition assessment (Canada, Chile, Egypt, Indonesia, Iceland, Israel, Malta, and Slovakia).

\subsection{Impact of integrating EU legislation in the indicators for EU and EFTA Member States}

26. As mentioned above, the EU and national institutions share responsibility in the enforcement of competition law in the European Union. Thus, indicators computed for EU Member States cover both the national and the EU competition regimes and are obtained by taking the simple average of the national and the EU scores. The EU competition rules also apply to Norway and Iceland and are enforced by the European Commission and the EFTA Surveillance Authority in a complementary manner. The indicators 
for these two countries are computed as for the EU Members States, i.e. an equal weight is attributed to the national and supranational competition authorities. ${ }^{27}$

Table 2. National competition laws and policies for EEA countries - set 1

\begin{tabular}{|c|c|c|c|c|}
\hline & Scope of action & $\begin{array}{c}\text { Policy on anticomp. } \\
\text { behaviour }\end{array}$ & $\begin{array}{c}\text { Probity of } \\
\text { investigation }\end{array}$ & Advocacy \\
\hline Austria & $0.29(0.14)$ & $0.00(0.00)$ & $1.80(0.90)$ & $1.29(0.86)$ \\
\hline Belgium & $0.29(0.14)$ & $0.00(0.00)$ & $0.00(0.00)$ & $0.86(0.64)$ \\
\hline Bulgaria & $0.00(0.00)$ & $0.63(0.32)$ & $0.00(0.00)$ & $1.29(0.86)$ \\
\hline Czech Republic & $0.29(0.14)$ & $0.00(0.00)$ & $0.00(0.00)$ & $0.43(0.43)$ \\
\hline Denmark & $0.57(0.29)$ & $0.00(0.00)$ & $0.00(0.00)$ & $0.00(0.21)$ \\
\hline Estonia & $0.29(0.14)$ & $0.00(0.00)$ & $1.80(0.90)$ & $0.86(0.64)$ \\
\hline Finland & $0.57(0.29)$ & $0.32(0.16)$ & $0.30(0.15)$ & $0.86(0.64)$ \\
\hline France & $0.00(0.00)$ & $0.00(0.00)$ & $0.00(0.00)$ & $0.86(0.64)$ \\
\hline Germany & $0.00(0.00)$ & $0.00(0.00)$ & $0.60(0.30)$ & $1.29(0.86)$ \\
\hline Greece & $0.29(0.14)$ & $0.32(0.16)$ & $0.00(0.00)$ & $0.86(0.64)$ \\
\hline Hungary & $00.0(0.00)$ & $0.32(0.16)$ & $1.20(0.60)$ & $0.86(0.64)$ \\
\hline Iceland & $0.00(0.07)$ & $0.00(0.16)$ & $0.30(0.15)$ & $1.71(1.61)$ \\
\hline Ireland & $0.57(0.29)$ & $0.63(0.32)$ & $0.30(0.15)$ & $0.43(0.43)$ \\
\hline Italy & $0.29(0.14)$ & $0.32(0.16)$ & $0.00(0.00)$ & $0.86(0.64)$ \\
\hline Latvia & $0.57(0.29)$ & $0.00(0.00)$ & $1.50(0.75)$ & $0.86(0.64)$ \\
\hline Lithuania & $0.29(0.14)$ & $0.00(0.00)$ & $0.90(0.45)$ & $1.29(0.86)$ \\
\hline Luxembourg & $2.00(1.00)$ & $1.26(0.63)$ & $1.71(0.60)$ & $3.00(1.71)$ \\
\hline Malta & $0.57(0.29)$ & $1.26(0.63)$ & $0.30(0.15)$ & $1.71(1.07)$ \\
\hline Netherlands & $0.57(0.29)$ & $0.63(0.32)$ & $0.30(0.15)$ & $0.86(0.64)$ \\
\hline Norway & $0.57(0.36)$ & $0.63(0.47)$ & $0.90(0.45)$ & $0.00(0.75)$ \\
\hline Poland & $0.29(0.14)$ & $0.00(0.00)$ & $0.90(0.45)$ & $0.86(0.64)$ \\
\hline Portugal & $0.29(0.14)$ & $0.00(0.00)$ & $0.00(0.00)$ & $1.29(0.86)$ \\
\hline Romania & $0.00(0.00)$ & $0.00(0.00)$ & $0.30(0.15)$ & $0.86(0.64)$ \\
\hline Slovakia & $0.00(0.00)$ & $0.63(0.32)$ & $0.90(0.45)$ & $1.71(1.07)$ \\
\hline Slovenia & $0.57(0.29)$ & $0.32(0.16)$ & $1.80(0.90)$ & $0.86(0.64)$ \\
\hline Spain & $0.00(0.00)$ & $0.00(0.00)$ & $0.15(0.08)$ & $0.43(0.43)$ \\
\hline Sweden & $0.57(0.29)$ & $0.00(0.00)$ & $1.20(0.60)$ & $1.29(0.86)$ \\
\hline United Kingdom & $0.57(0.29)$ & $0.00(0.00)$ & $0.15(0.08)$ & $0.00(0.21)$ \\
\hline
\end{tabular}

Note: The indicators that reflect both national and EEA competition law and policy are presented in brackets.

27. The scores of EU Member States generally improve when taking into account EEA legislation since the European Commission is scored 0 for all indicators but advocacy. ${ }^{28}$ Hence, the scores for EU Member States are generally cut in half (i.e. improve) when the EU regime is incorporated (Table 2 and Table A1.15 in Annex 1). In the case of advocacy, the decline is smaller and the scores of Denmark and the United Kingdom even go up when the EU is taken into account. The picture is less clear for Norway and Iceland. The EFTA Surveillance Authority has higher scores compared with the Commission for 'scope of action', 'policy on anticompetitive behaviour' and 'advocacy'. ${ }^{29}$ Hence, when integrating information on

27. As for EU Member States, the national score accounts for one half of the indicator value. The scores of the European Commission and the EFTA Surveillance Authority respectively account for one quarter of the indicator value, which provides a weight of one half to the supranational authorities.

28. The EU Commission scores 0.4 for the indicator on advocacy because the Commission is not obliged to respond to the recommendations included in the market studies performed at the EU level (but usually do so).

29. The EFTA Surveillance Authority has taken less action against anticompetitive behaviours than the European Commission over the past few years. Over the past ten years, the Authority has not imposed sanctions on a firm and/or individuals for hindering an investigation. It has not blocked or cleared a merger 
the EEA competition regime, the scores of Iceland and Norway increase for 'advocacy'. The score of Iceland also rises for 'scope of action' and 'policy on anti-competitive behaviour'. Indicators that do not incorporate the EEA legislation (as shown in Table 2) could be used to investigate differences across the national institutions enforcing competition law in the European Economic Area.

\subsection{Robustness tests}

28. Composite quantitative indicators that are derived from lower-level qualitative information are prone to aggregation errors, reflecting uncertainty regarding the appropriate weighting scheme. Ideally the weighting scheme should reflect the relative contribution of each observation to the effectiveness of the competition regime but this is unknown a priori. To make clear what arbitrary assumptions are used and to facilitate the reading of the results, equal weights are used to construct the indicators. Two types of tests one based on random weights and one based on a factor analysis - are used to investigate how sensitive the cross-country differences in the various dimensions of competition law and policy are to the choice of the weighting scheme.

29. The random weights analysis consists in re-computing the indicators using randomly drawn weights for the aggregation. This technique consists of generating 10000 sets of weights and calculating 10000 corresponding values of the indicators by aggregating individual questions based on these weights. The random weights are drawn from a uniform distribution between zero and one and are then normalised so that they sum to unity. ${ }^{30}$ The 10000 indicator values are used to compute $90 \%$ confidence intervals around the mean value of each indicator. ${ }^{31}$ Indicators with a relatively large confidence interval (i.e. indicators that can take a wide range of different values depending on the weighting scheme used) are more difficult to interpret.

30. The random weight exercise shows that the weighting scheme has an impact on the values of the indicators. In a number of cases, differences in the values of the indicators across countries vanish once the $90 \%$ confidence intervals are considered (Figure 7). ${ }^{32}$ The $90 \%$ confidence intervals are larger for the indicators of 'probity of investigation' and 'advocacy' compared to those of 'scope of action' and 'policy on anticompetitive behaviours'. This might be due to the fact that a large number of observations have the same score (zero in many cases) in the latter two indicators. These large confidence intervals indicate that the relatively high variability of the indicators for probity of investigation and advocacy relates to some extent to the weighting scheme used and that some differences in the values of these indicators are not statistically significant. ${ }^{33}$

and has not imposed sanctions or remedies on a cartel over the past five years. Also, it does not advocate competition at local government levels and cannot provide recommendations in its market studies.

30. In absence of knowledge about the probability distribution of the weights, the choice of a uniform distribution was made for simplicity.

31. This shows the range of values the indicator takes in $90 \%$ of the cases among the 10000 draws.

32. The scores of jurisdictions are considered as significantly different when their confidence intervals do not overlap.

33. The variability of the indicators is measured by their standard deviation. Standard deviation of "probity of investigation' and 'advocacy' amounts to around 0.6 and 0.7 respectively compared with 0.4 for 'scope of action' and 'policy on anticompetitive behaviours'. 
Figure 7. Results of the random weights exercise

Panel A. Scope of action

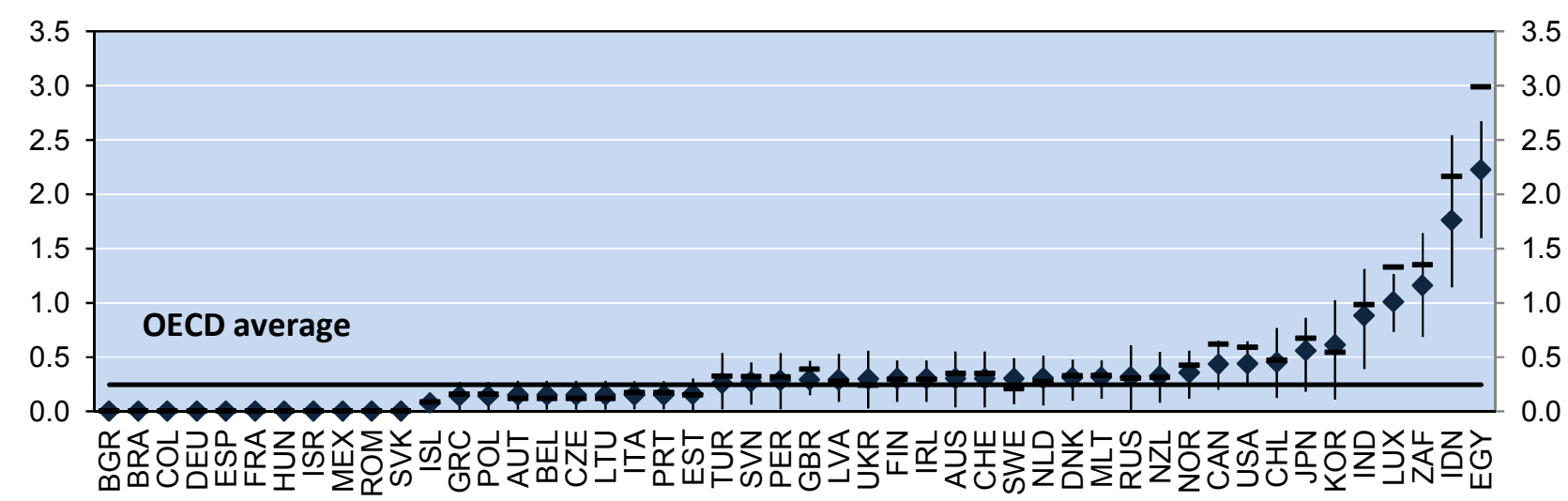

Panel B. Policy on anticompetitive behaviour

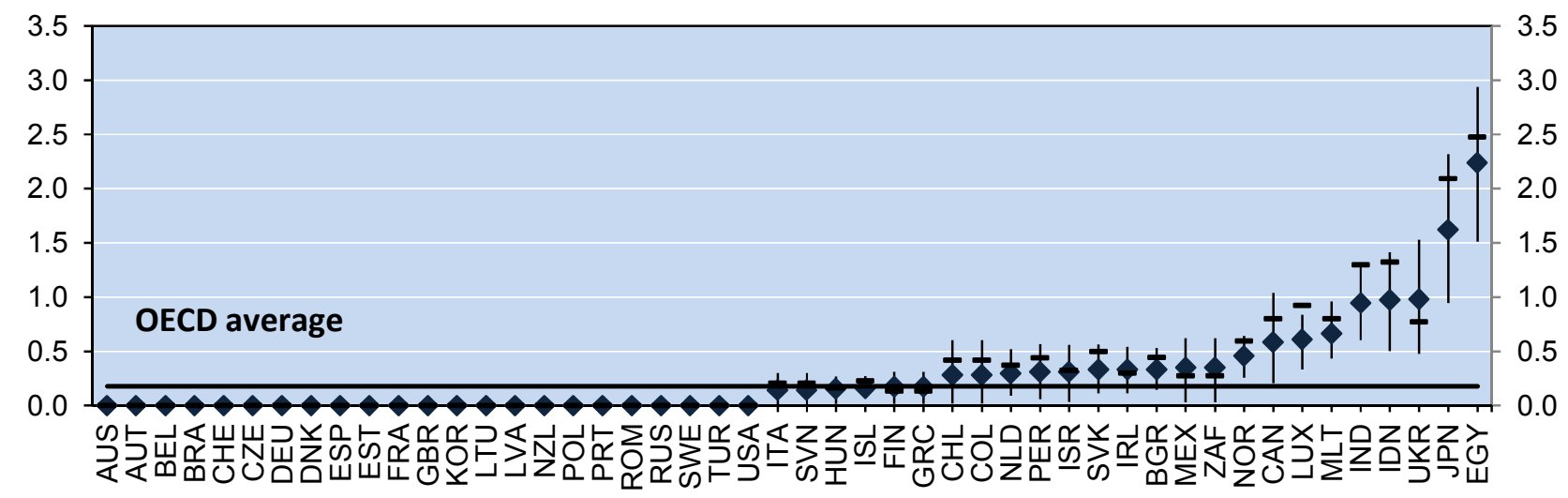

Panel C. Probity of investigation

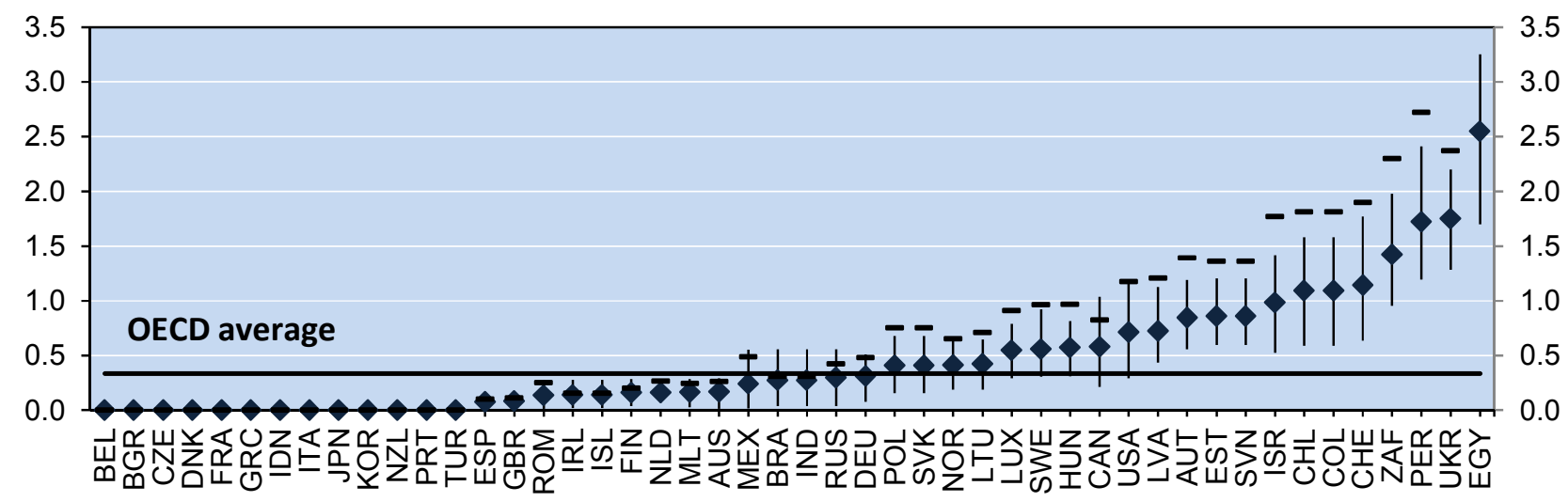

Note: The diamonds show the mean estimates and the lines indicate the $90 \%$ confidence interval obtained with the random weight exercise. The horizontal bar shows the factor analysis estimates. The OECD average is based on the indicators obtained with the random weights exercise. 
Figure 7. Results of the random weights exercise (continued)

Panel D. Advocacy

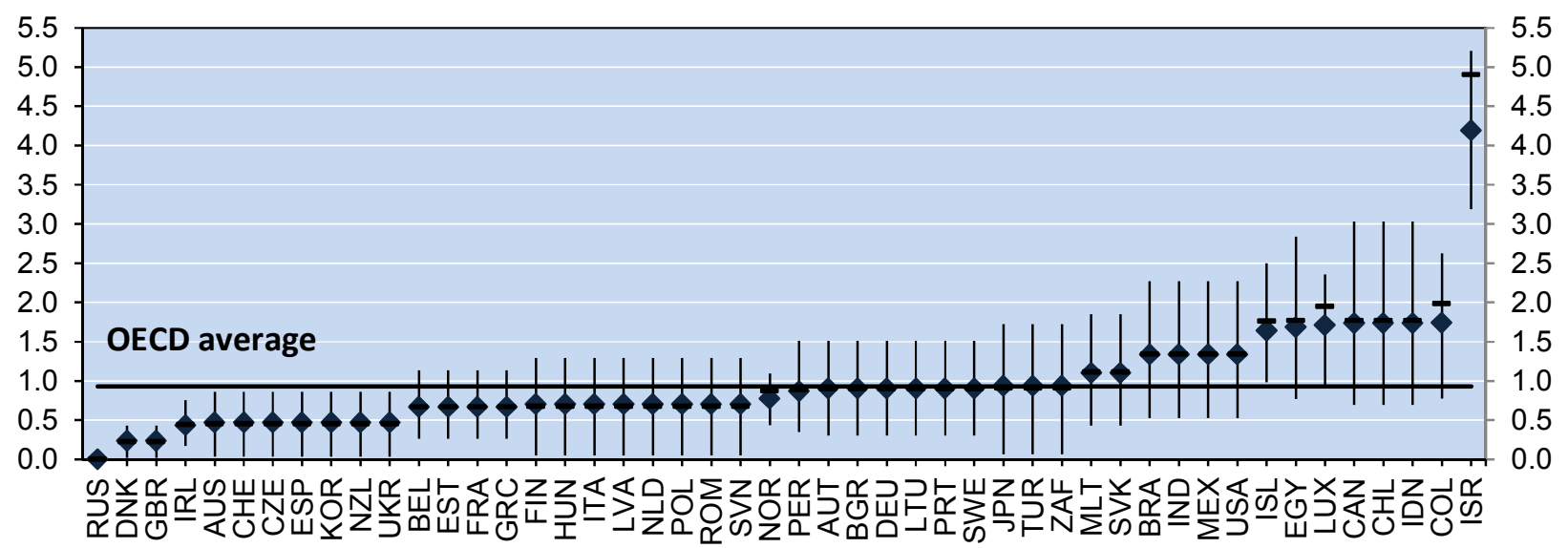

Note: The diamonds show the mean estimates and the lines indicate the $90 \%$ confidence interval obtained with the random weight exercise. The horizontal bar shows the factor analysis estimates. The OECD average is based on the indicators obtained with the random weights exercise.

31. Despite the sensitivity of the results to the weighting scheme, it is still possible to identify groups of countries with scores that are statistically different, for instance, groups of countries that significantly deviate from the OECD average (Table 3 ). ${ }^{34}$ While the composition of these groups tends to vary across indicators, some jurisdictions have a stronger competition regime than the OECD average for most of the four more aggregated indicators (Australia, Czech Republic, Denmark, Korea, France, Spain, and the United Kingdom) and others underperform compared to the average for three out of the four indicators (Egypt and Luxembourg). ${ }^{35}$

32. The second robustness test - based on factor analysis - also indicates that two groups of countries could be distinguished as regards the effectiveness of their competition regime. The factor analysis is a statistical technique that allows to identify the relative contribution of each component of the competition regimes captured in the questionnaire to the overall variance in the data. In other words, it highlights the components that contribute more to the variance of information across countries. The contributions of each component could be used as weights to compute the indicators as done, for instance, in Nicoletti et al. (1999). ${ }^{36}$ The indicators of 'scope of action', 'policy on anticompetitive behaviours' and 'advocacy' obtained with this technique are generally close to those obtained with the equal weights (Figure 7). By contrast, the indicator of 'probity of investigation' is systematically above the one measured with equal weights. This is due to the fact that this indicator includes a relatively high number of questions for which the jurisdictions have the same scores (in general a zero score). These questions do not contribute to the variance in the data and are thus not included in the calculation of the indicator. As a result, the questions including non-null observations have a significantly higher weight in the indicator

34. When the confidence interval of a score does not include the OECD average, the score is considered as statistically different from the average (above or below). Jurisdictions with scores above and below the average are grouped and presented in Table 3.

35. It should be borne in mind that the differences in scores might be driven by one or two questions and thus might not be significant in an economic sense.

36. This means that the largest weights are assigned to those questions that have the largest variation across countries. This technique was used to compute the initial version of the PMR indicators. Details on the method are provided in Annex A2. 
obtained with the factor analysis than in the indicator obtained with equal weights, inducing larger values for the former. Nevertheless, the positions of jurisdictions relative to the OECD average shown in Table 3 remain broadly unchanged. ${ }^{37}$

Table 3. Country groupings implied by the random weights analysis

\begin{tabular}{|c|c|c|c|c|}
\hline & Scope of action & $\begin{array}{c}\text { Policy on } \\
\text { anticompetitive } \\
\text { behaviour }\end{array}$ & Probity of investigation & Advocacy \\
\hline $\begin{array}{l}\text { Competition } \\
\text { regimes more } \\
\text { conductive to } \\
\text { competition } \\
\text { compared to the } \\
\text { OECD-average }\end{array}$ & $\begin{array}{c}\text { Brazil, Bulgaria, } \\
\text { Columbia, Germany, } \\
\text { Spain, France, Hungary, } \\
\text { Iceland, Israel, Mexico, } \\
\text { Romania, } \\
\text { Slovak Republic }\end{array}$ & $\begin{array}{c}\text { Australia, Austria, } \\
\text { Belgium, Brazil, } \\
\text { Czech Republic, } \\
\text { Denmark, Germany, } \\
\text { Spain, Estonia, } \\
\text { France, } \\
\text { United Kingdom, } \\
\text { Korea, Lithuania, } \\
\text { Latvia New Zealand, } \\
\text { Poland, Portugal, } \\
\text { Romania, } \\
\text { Russia, Switzerland, } \\
\text { Sweden, Turkey, } \\
\text { United States }\end{array}$ & $\begin{array}{c}\text { Australia, Belgium, } \\
\text { Bulgaria, } \\
\text { Czech Republic, } \\
\text { Denmark, Spain, } \\
\text { Finland, France, } \\
\text { United Kingdom, } \\
\text { Greece, Indonesia, } \\
\text { Iceland, Ireland, Italy, } \\
\text { Japan, Korea, Malta, } \\
\text { Netherlands, } \\
\text { New Zealand, Portugal, } \\
\text { Romania, Turkey }\end{array}$ & $\begin{array}{c}\text { Australia, } \\
\text { Czech Republic, } \\
\text { Denmark, } \\
\text { United Kingdom, } \\
\text { Ireland, Korea, New } \\
\text { Zealand, Spain, } \\
\text { Switzerland, Russia, } \\
\text { Ukraine }\end{array}$ \\
\hline $\begin{array}{l}\text { Competition } \\
\text { regimes less } \\
\text { conductive to } \\
\text { competition } \\
\text { compared to the } \\
\text { OECD-average }\end{array}$ & $\begin{array}{l}\text { Egypt, Indonesia, India, } \\
\text { Luxembourg, } \\
\text { South Africa }\end{array}$ & $\begin{array}{c}\text { Canada, Egypt, } \\
\text { Indonesia, India, } \\
\text { Japan, Luxembourg } \\
\text { Malta, Norway, } \\
\text { Ukraine }\end{array}$ & $\begin{array}{l}\text { Austria, Columbia, } \\
\text { Switzerland, Chile, } \\
\text { Egypt, Estonia, Israel, } \\
\text { Latvia, Peru, Slovenia, } \\
\text { Ukraine, South Africa }\end{array}$ & $\begin{array}{l}\text { Iceland, Israel, } \\
\text { Luxembourg }\end{array}$ \\
\hline
\end{tabular}

Note: Countries which are in the same group (i.e. 'Above OECD average effectiveness', 'Below OECD average effectiveness') for at least three out of four indicators are highlighted in bold.

33. The weighting scheme obtained with the factor analysis maximises the variations in the indicators. The counterpart is that a range of information contained in the data is ignored by the indicators (i.e. those questions for which there is no variation across countries). Since providing a comparative analysis of competition regimes across countries is one of the purposes of the indicator set, omitting the questions without variability is a serious drawback as these questions provide insights into which policies and practices are uniformly adopted by all countries. Furthermore, this type of weighting scheme is sensitive to modifications in the data. Weights used to compute the indicators are likely to change with data revisions and up-dates, hampering the comparability of the indicators over time. For these reasons, equal weights rather than the 'factor analysis' weights have been used to compute the CLP indicators. Future refinement of the indicators should aim at computing a weighting scheme that better reflects the relative contribution of each question to the effectiveness of competition regimes.

\subsection{Correlation analysis}

34. This section is a first attempt to assess the empirical linkages between the CLP indicators and other policy indicators. The section assesses the correlation between the four more aggregated CLP indicators and other policy indicators, i.e. the indicator on competition enforcement published in the Global Competition Review (GCR), the indicator on the effectiveness of anti-monopoly policy published by the World Economic Forum (WEF) in the annual Global Competition Report, the OECD PMR indicators and

37. The scores of the jurisdictions are compared with the average level of the indicators values obtained with the factor analysis method in the OECD. The average is close to the average obtained with the random weights for all indicators, but for the indicator of 'probity of investigation' ( 0.6 versus 0.4$)$. 
the World Bank's Worldwide Governance Indicators (WGI). Because this assessment is based on a simple correlation analysis, it does not allow to determine causality links but only to identify possible relationships between the indicators. They should thus be interpreted with caution.

35. Most of the four CLP indicators are positively correlated with each other, but with a correlation varying from around 0.3 to 0.7 (Table 4 ). ${ }^{38}$ The level of correlation is quite low for most combinations of indicators, suggesting that further aggregating the information into one single composite indicator might not be appropriate. Only the indicators of 'scope for action' and 'policy on anticompetitive behaviours' might be combined since the correlation between them is close to 1 . This strong correlation indicates that those jurisdictions that allow more actions against anticompetitive behaviours by law are also those that are the most active against these behaviours in practice.

Table 4. Correlation of competition law and policy indicators

OECD CLP (set 1), GCR and WEF indicators

\begin{tabular}{lcccccc}
\hline & $\begin{array}{c}\text { Scope of } \\
\text { action }\end{array}$ & $\begin{array}{c}\text { Policy on anti- } \\
\text { comp. behav. }\end{array}$ & $\begin{array}{c}\text { Probity of } \\
\text { investigation }\end{array}$ & Advocacy & GCR & WEF \\
\hline Scope of action & 1.00 & $0.73^{* * *}$ & $0.40^{* *}$ & 0.19 & 0.17 & 0.03 \\
Policy on anticomp. behaviour & - & 1.00 & $0.43^{* *}$ & $0.33^{* *}$ & 0.05 & -0.19 \\
Probity of investigation & - & - & 1.00 & $0.31^{* *}$ & -0.17 & $-0.25^{*}$ \\
Advocacy & - & - & - & 1.00 & -0.12 & -0.11 \\
GRC & - & - & - & - & 1.00 & $0.39^{* *}$ \\
WEF & - & - & - & - & - & 1.00 \\
\hline
\end{tabular}

Note: WEF refers to the indicator on the effectiveness of the anti-monopoly policy published in the Global Competitiveness Report 2012-2013 by the World Economic Forum. GCR refers to the indicator of the Global Competition Review on competition enforcement and is the average of this indicator between 2010 and 2013. The results do not change when the correlation coefficients are calculated with the GCR indicator for 2013. Asterisks $\left({ }^{*},{ }^{* *},{ }^{* *}\right)$ indicate the significance level $(10 \%, 5 \%, 1 \%)$ of the correlation coefficients.

Source: Global Competition Review, Rating enforcement 2010, 2011, 2012, 2013; World Economic Forum, Global Competitiveness Report 2012-2013.

36. The CLP indicators are not correlated with the GCR and the WEF indicators, two indicators that are widely used to assess competition regimes (see the last two columns of Table 4). This is not surprising insofar as the indicators do not cover the same policy areas. The information captured by the GCR indicator is complementary to that of the CLP indicators, with a strong focus on de facto information, such as the level of resources of competition agencies (financial and human) and the number of cases addressed in the jurisdiction over the past year. ${ }^{39}$ Furthermore, the GCR and WEF rely on subjective assessments. The WEF indicator is based on a survey of top business executives regarding their perception of the effectiveness of the antimonopoly policy. ${ }^{40}$ It is simplistic as it is based on a single question and thus does not capture the different dimensions of competition law and policy reflected in the CLP indicators. Also, since it is based on people's perceptions, the indicator may be biased by executives' beliefs or economic conditions (Bertrand and Mullainathan, 2001; Olken, 2009).

38. Only the correlation between 'scope of action' and 'advocacy' is not significantly different from zero. A simple test for statistical significance concludes that there is no correlation if correlation is below 0.3 .

39. The GCR rating of competition agencies varies from 2 for the least effective agency to 5 for the most effective agency.

40. Business executives are asked to what extent anti-monopoly policy promotes competition in their country (answer choices range from 1 for 'does not promote competition' to 7 for 'effectively promotes competition'). 
37. Correlations between the CLP indicators and the World Bank's Worldwide Governance Indicators (WGI) are also examined. ${ }^{41}$ The results suggest that jurisdictions where the governance is perceived as of good quality might be also those where the competition laws and policies are closer to best practice according to the CLP indicators. Each WGI indicator is positively correlated with at least two CLP indicators. In particular, a link is found between indicators for 'scope of action', 'policy on anticompetitive behaviours', and 'probity of investigation' and the World Bank's indicators of 'regulatory quality' which reflects perceptions of the government's ability to formulate and implement sound policies and regulations which permit and promote private sector development. These three CLP indicator are also significantly correlated with the indicator of 'government effectiveness' which captures the quality of public services, the degree of independence of the civil service from political pressures, the quality of policy formulation and implementation, and the credibility of the government's commitment to such policies. These relationships might not be robust nor causal as they do not take into account other factors that might play a role in both the quality of governance and the effectiveness of competition policy (for instance the level of resources devoted to ensure the good functioning of the institutions).

Table 5. Correlation between CLP and WGI indicators

\begin{tabular}{lcccc}
\hline & Scope of action & $\begin{array}{c}\text { Policy on anticomp. } \\
\text { behav. }\end{array}$ & $\begin{array}{c}\text { Probity of } \\
\text { investigation }\end{array}$ & Advocacy \\
\hline Control of corruption & -0.17 & $-0.24^{*}$ & $-0.27^{*}$ & -0.07 \\
Rule of law & -0.21 & $-0.30^{* *}$ & $-0.31^{* *}$ & -0.11 \\
Regulatory quality & $-0.34^{* *}$ & $-0.41^{* * *}$ & $-0.29^{* *}$ & -0.09 \\
Government effectiveness & $-0.27^{*}$ & $-0.35^{* *}$ & $-0.34^{* *}$ & -0.08 \\
\hline
\end{tabular}

Note: Asterisks $\left({ }^{*},{ }^{* *},{ }^{* *}\right)$ indicate the significance level $(10 \%, 5 \%, 1 \%)$ of the correlation coefficients. The negative correlation indicate a positive link between the quality of governance and the effectiveness of competition regime, the CLP indicators varying from 0 to 6 from the most to the least effective regime and the WDI indicators varying between around -2.5 and 2.5 from the lowest to the highest quality of governance.

Source: Worldwide Governance Indicators (WGI), World Bank.

38. The CLP indicators are generally not correlated with the OECD PMR indicators (Table 5). ${ }^{42}$ Taken at face value, this would suggest that countries where product market regulations are conducive to competition and growth are not necessarily the countries with the most effective competition regimes (as measured by the CLP indicators). At the same time, a positive and significant correlation is found between a few PMR and CLP indicators. The PMR indicator on 'regulatory protection of incumbents' is positively linked with the CLP indicators on 'advocacy', 'policy on anticompetitive behaviours', and 'scope of action'. The first correlation suggests that competition advocacy might play a role in designing good regulation, notably as regards regulatory entry barriers. The second and third correlation may show that countries with legal regulatory barriers to competition, such as restrictions on the number of firms allowed to operate a business in some markets, exemptions to public firms to competition law, or restrictive conditions for third parties access in networks sectors, do not have strong competition regimes. The PMR indicator of 'barriers to trade and investment' captures the restrictions to foreign direct investment and the

41. The World Bank's Worldwide Governance Indicators (WGI) measure the quality of public governance, i.e. the traditions and institutions by which authority in a country is exercised, in six areas (Voice and Accountability, Political Stability and Absence of Violence, Government Effectiveness, Regulatory Quality, Rule of Law, Control of Corruption) for 215 economies over the period 1996-2012.

42. The PMR indicators aim at describing patterns and developments of regulation that potentially affect product market competition. The indicator set comprises one aggregate indicator, three high-level components, which are broken down into seven mid-level indicators (used in Table 5) and eighteen lowlevel indicators. It covers 33 OECD and 21 non-OECD countries. 
tariffs barriers. It is positively correlated with the indicator of 'probity of investigation' and 'policy on anticompetitive behaviours', indicating that open economies may be more likely than others to adopt best practices regarding the independence of the bodies enforcing competition law, the fairness of the investigative procedure, and the accountability of the competition regime as well as to take action against antitrust infringement. Nevertheless, such tentative interpretation of simple correlations would need to be further investigated and should thus be interpreted with a lot of caution.

Table 6. Correlation between CLP and PMR indicators

\begin{tabular}{lcccc}
\hline & Scope of action & $\begin{array}{c}\text { Policy on anticomp. } \\
\text { behav. }\end{array}$ & $\begin{array}{c}\text { Probity of } \\
\text { investigation }\end{array}$ & Advocacy \\
\hline Product market regulation & -0.04 & 0.00 & 0.22 & $0.27^{*}$ \\
Public ownership & 0.10 & -0.05 & -0.12 & -0.07 \\
Involvement in business operation & 0.18 & 0.17 & 0.14 & 0.24 \\
Complexity of regulatory procedures & 0.06 & 0.07 & 0.21 & 0.23 \\
Administrative burdens on start-ups & -0.14 & 0.03 & -0.09 & 0.14 \\
Regulatory protection of incumbents & $0.26^{*}$ & $0.30^{* *}$ & 0.12 & $0.33^{* *}$ \\
Explicit barriers to trade and investment & 0.22 & $0.27^{*}$ & $0.26^{*}$ & 0.23 \\
\hline Other barriers to trade and investment & -0.06 & 0.15 & 0.20 & 0.23 \\
\hline
\end{tabular}

Source: Preliminary 2013 Product Market Regulation Indicators

39. Further empirical work is needed to interpret these results and investigate the link between the indicators and economic outcomes. Future empirical work could explore the interactions between the CLP indicator and other policy indicators. In particular, the interactions with the PMR indicators should be investigated as these two indicators assess policy areas that contribute to growth in a complementary manner. The effectiveness of the competition regimes might have a bigger impact on growth in jurisdictions or sectors where regulation of product market is more conducive to competition (because in strictly regulated sectors, product market regulation might directly determine the competition level). Conversely, in countries where product market regulation is restrictive, an effective competition regime could partly mitigate the negative impact of a strict regulation on economic performance (for instance in sectors where a significant share of the activity is state-controlled). Clustering analysis could be carried out to identify groups of countries with comparable policy settings, i.e. characterised by a specific combination of policy instruments. This analysis could include the PMR indicators in order to assess the complementarity of product market regulation and competition law and policy. 
ECO/WKP(2013)96

\section{REFERENCES}

Ahn, S. (2002), "Competition, innovation and productivity growth: A review of theory and evidence", OECD Economics Department Working Papers, No. 317.

Bertrand, M. and S. Mullanaithan, (2001), "Do people mean what they say? Implications for subjective survey data", American Economic Review, vol. 91(2), pp. 67-72.

Buccirossi, P., L. Ciari, T. Duso, G. Spagnolo and C. Vitale (2011), "Measuring the deterrence properties of competition policy the competition policy indices", Journal of Competition Law and Economics, Vol. 7, pp. 1-40.

Buccirossi P., L. Ciari, T. Duso, G. Spagnolo and C. Vitale (2013), "Competition policy and productivity growth: An empirical assessment”, The Review of Economic and Statistics, Vol. 95(4), pp. 1324-1336.

Conway, P., V. Janod and G. Nicoletti (2005), "Product market regulation in OECD Countries: 1998 to 2003”, OECD Economics Department Working Papers, No. 419.

Conway, P., D. de Rosa, G. Nicoletti and F. Steiner (2006), "Regulation, competition and productivity convergence", OECD Economics Department Working Papers, No. 509, OECD Publishing.

Disney R., J. Haskel and Y. Heden (2000), "Restructuring and productivity growth in UK manufacturing", CEPR Discussion Paper, $\mathrm{n}^{\circ} 2463$.

European Commission, (2004), "Commission notice on cooperation within the network of competition authorities, Official Journal of the European Union, C 101/43

Høj, J. (2007), "Competition law and policy indicators for the OECD countries", OECD Economics Department Working Papers, No. 568.

Koske, I., I. Wanner, R. Bitetti, and O. Barbiero (2013), "The 2013 OECD product market regulation indicators: policy insights for OECD and non-OECD countries", OECD Economics Department Working Papers, forthcoming.

Nickell, S. J. (1996), "Competition and corporate performance", Journal of Political Economy, Vol. 104, pp. $724-746$.

Nicoletti, G., S. Scarpetta and O. Boylaud (1999), "Summary indicators of product market regulation with an extension to employment protection legislation", OECD Economics Department Working Papers, No 226.

Nicoletti, G. and S. Scarpetta, (2003), "Regulation, productivity and growth: OECD evidence", Economic Policy, No18, pp. 9-72.

Nicodème, G. and J.-B. Sauner-Leroy (2007), "Product market reforms and productivity: A review of the theoretical and empirical literature on the transmission channels", Journal of Industry, Competition and Trade, Vol.7, ${ }^{\circ} 1$, pp.53-72.

OECD (2002), Fighting Hard Core Cartels: Harm, Effective Sanctions and Leniency Programmes, OECD Publishing. 
ECO/WKP(2013)96

OECD (2007), "Guidance to business on monopolisation and abuse of dominance", Policy Roundtable, Competition Law and Policy", OECD Publishing.

OECD (2012), "The role of efficiency claims in antitrust proceedings", Policy Roundtable, Competition Law and Policy, OECD Publishing.

OECD (2013), Economic Policy Reforms 2013, Going for Growth, OECD Publishing

Olken, B. (2009), "Corruption perceptions vs. corruption reality", Journal of Public Economics, vol. 93(7-8), pp. 950-964.

Wölfl, A., I. Wanner, T. Kozluk, and G. Nicoletti (2009), “Ten years of product market reform in OECD countries - insights from a revised PMR indicator", OECD Economics Department Working Papers, No. 695 .

Wölfl, A., I. Wanner, O. Röhn, and G. Nicoletti (2010), "Product market regulation: extending the analysis beyond OECD countries", OECD Economics Department Working Papers, No. 799. 
ECO/WKP(2013)96

\section{ANNEX A1. DETAILED PRESENTATION OF THE CLP INDICATORS}

40. This annex presents in more detail the two sets of CLP indicators. As mentioned in the main text, the first (more aggregated) set includes four indicators and the second (more disaggregated) set includes twelve indicators (presented in Table A1.14). ${ }^{43}$ The same database, scoring, and aggregation method are used to construct these indicators. All indicators are measured as the simple average of the data points that belong to them. The scoring system is detailed below starting with the more disaggregated set of indicators.

\section{Presentation of the more disaggregated set of indicators (set 2)}

\section{Competences}

41. A competition regime is weaker if some firms are exempted from the provisions of the competition law. The indicator on competences is the simple average of two components: $(i)$ exemptions for firms located outside the jurisdiction and (ii) exemptions for publicly-controlled firms (Table A1.1). Those jurisdictions that apply their competition law to foreign firms are scored 0 and those that do not are scored 6. If the competition law fully applies to publicly-controlled firms the jurisdiction is scored 0 and if publicly-control firms are totally exempted from competition law, the jurisdiction is scored 6 . When the exemptions of publicly-controlled firms are limited to some sectors and/or to some antitrust infringement, the jurisdiction is scored 3.

Table A1.1. Scoring of the questions on competences

\begin{tabular}{lc}
\hline \multicolumn{1}{c}{ Question } & Score \\
\hline $\begin{array}{l}\text { Does the competition law apply also to firms located outside your } \\
\text { jurisdiction whose behaviour directly affects competition and/or } \\
\text { consumers in domestic markets? (Q1.1) }\end{array}$ & $\begin{array}{c}\text { yes }=0 \\
\text { no }=6\end{array}$ \\
$\begin{array}{l}\text { In your jurisdiction, are state-controlled firms exempt from the } \\
\begin{array}{l}\text { application of competition law when conducting commercial } \\
\text { activities in competition with private firms? (Q1.2) }\end{array}\end{array}$ & $\begin{array}{c}\text { yes }=6 \\
\text { yespect to some antitrust infringements }=3 \\
\text { no }=0\end{array}$ \\
\hline
\end{tabular}

\section{Powers to investigate}

42. The range of investigative powers available to the institutions that enforce competition law influences their ability to protect competition. This indicator is an average of six observations assessing whether it is possible to obtain information by compelling firms and third parties to cooperate, as well as by performing unannounced inspections (Table A1.2). If the competition agency or courts can compel firms and third parties to provide information to help with an investigation on an antitrust infringement or a merger, the jurisdiction is scored 0 ( 6 otherwise). If unannounced inspections are possible, the jurisdiction is scored 0 ( 6 otherwise). A de facto question asks whether at least one unannounced inspection has been performed in the past five years (if yes, the jurisdiction is scored 0 , if not it is scored 6).

43. For EU Member States, Norway, and Iceland, the indicators reflect both national and EU competition law and policy. For purpose of comparison, the indicators reflecting only the national competition regime of these countries are also presented in Table A1.15. 
Table A1.2 Scoring of the questions on powers to investigate

\begin{tabular}{|c|c|}
\hline Question & Score \\
\hline $\begin{array}{l}\text { Can your competition agency compel (or ask a court to compel) firms } \\
\text { investigated for a possible antitrust infringement to provide information? (Q3.1) }\end{array}$ & $\begin{array}{l}\text { yes }=0 \\
\text { no }=6\end{array}$ \\
\hline $\begin{array}{l}\text { Can your competition agency compel (or ask a court to compel) third parties to } \\
\text { provide information to help an investigation on an antitrust infringement? } \\
\text { (Q3.2) }\end{array}$ & $\begin{array}{c}\text { yes }=0 \\
\text { no }=6\end{array}$ \\
\hline $\begin{array}{l}\text { Can your competition agency perform unannounced inspections/searches in } \\
\text { the premises of firms investigated for a possible antitrust infringement aimed at } \\
\text { gathering evidence (with or without a warrant/court authorisation)? (Q3.3) }\end{array}$ & $\begin{array}{l}\text { yes }=0 \\
\text { no }=6\end{array}$ \\
\hline $\begin{array}{l}\text { If yes, has your competition agency performed unannounced inspections in the } \\
\text { premises of firms investigated for a possible antitrust infringement at least } \\
\text { once in the last five years? (Q3.4) }\end{array}$ & $\begin{array}{c}\text { yes }=0 \\
\text { no }=6 \\
\text { not applicable }=6\end{array}$ \\
\hline $\begin{array}{l}\text { Can your competition agency compel (or ask a court to compel) merging firms } \\
\text { to provide information to help it assess the merger? (Q3.5) }\end{array}$ & $\begin{array}{l}\text { yes }=0 \\
\text { no }=6\end{array}$ \\
\hline $\begin{array}{l}\text { Can your competition agency compel (or ask a court to compel) third parties to } \\
\text { provide information to help it assess the merger? (Q3.6) }\end{array}$ & $\begin{array}{l}\text { yes }=0 \\
\text { no }=6\end{array}$ \\
\hline
\end{tabular}

\section{Powers to sanction and remedy}

43. For an effective competition regime it is also important that the institutions enforcing competition law have sufficient powers to punish or remedy behaviours and mergers that restrict or distort competition. This indicator is an average of ten questions dealing with the powers to take action against anticompetitive behaviours and mergers (Table A1.3). The actions covered by the indicator include imposing sanctions and remedies for antitrust infringements, blocking or remedying anticompetitive mergers, limiting the cost of the procedure by shortening the length of the investigative process and reducing the damages that such behaviours can cause by imposing interim measures. A jurisdiction is scored 0 if these actions are possible and 6 otherwise. ${ }^{44}$ One de facto question is also included: a jurisdiction is scored 0 if the agency or courts have imposed sanctions on firms that have hindered an investigation at least once over the past ten years.

44. In some jurisdictions, remedies, cease and desist order, commitments, and interim measures usually do not apply to hard-core agreement. In such cases, the jurisdiction should be scored 0 . 
ECO/WKP(2013)96

Table A1.3. Scoring of the questions on powers to sanction and remedy

\begin{tabular}{|c|c|}
\hline Question & Score \\
\hline $\begin{array}{l}\text { Can your competition agency impose (or ask a court to impose) } \\
\text { remedies or a cease and desist order on firms that have } \\
\text { committed an antitrust infringement? (Q4.1) }\end{array}$ & $\begin{array}{c}\text { yes, for all antitrust infringements }=0 \\
\text { yes, but only for some antitrust infringements }=0 \\
\text { no }=6\end{array}$ \\
\hline $\begin{array}{l}\text { If yes, can your competition agency impose (or ask a court to } \\
\text { impose) sanctions on firms that do not comply with remedies } \\
\text { imposed on them with respect to an antitrust infringement they } \\
\text { have committed? (Q4.2) }\end{array}$ & $\begin{array}{c}\text { yes }=0 \\
\text { no }=6 \\
\text { not applicable }=6\end{array}$ \\
\hline $\begin{array}{l}\text { Can your competition agency impose (or ask a court to impose) } \\
\text { sanctions on firms that have committed an antitrust } \\
\text { infringement? (Q4.3) }\end{array}$ & $\begin{array}{c}\text { yes, for all antitrust infringements }=0 \\
\text { yes, but only for some antitrust infringements }=0 \\
\text { no }=6\end{array}$ \\
\hline $\begin{array}{l}\text { Can your competition agency (or a court) accept or impose } \\
\text { remedies on firms in order to clear a merger? (Q4.4) }\end{array}$ & $\begin{array}{l}\text { yes }=0 \\
\text { no }=6\end{array}$ \\
\hline $\begin{array}{l}\text { Can your competition agency impose (or ask a court to impose) } \\
\text { sanctions on a firm that hinders an investigation on an alleged } \\
\text { antitrust infringement? (Q4.5) }\end{array}$ & $\begin{array}{c}\text { yes }=0 \\
\text { no }=6\end{array}$ \\
\hline $\begin{array}{l}\text { If yes, have sanctions been imposed on a firm and/or individuals } \\
\text { for hindering an investigation on an antitrust infringement at least } \\
\text { once in the last ten years? (Q4.6) }\end{array}$ & $\begin{array}{c}\text { yes }=0 \\
\text { no }=6 \\
\text { not applicable }=6\end{array}$ \\
\hline $\begin{array}{l}\text { Can your competition agency impose (or ask a court to impose) } \\
\text { sanctions on firms and/or individuals that do not comply with a } \\
\text { decision concerning a merger? (Q4.7) }\end{array}$ & $\begin{array}{c}\text { yes }=0 \\
\text { no }=6\end{array}$ \\
\hline $\begin{array}{l}\text { Can your competition agency impose (or ask a court to impose) } \\
\text { interim measures while performing an investigation of an alleged } \\
\text { antitrust infringement because there is a concern that this may } \\
\text { lead to irreversible damages?(Q4.8) }\end{array}$ & $\begin{array}{c}\text { yes, for all antitrust infringements }=0 \\
\text { yes, but only for some antitrust infringements }=0 \\
\text { no }=6\end{array}$ \\
\hline $\begin{array}{l}\text { Can your competition agency (or a court) settle voluntarily with } \\
\text { the parties investigated for an alleged antitrust infringement and } \\
\text { thus close the investigation?(Q4.9) }\end{array}$ & $\begin{array}{c}\text { yes, for all antitrust infringements }=0 \\
\text { yes, but only for some antitrust infringements }=0 \\
\text { no }=6\end{array}$ \\
\hline $\begin{array}{l}\text { Can your competition agency (or a court) clear a merger that } \\
\text { raises anticompetitive concerns by negotiating/accepting } \\
\text { remedies that address these concerns at an early stage and thus } \\
\text { avoid performing a more in-depth investigation? (Q4.10) }\end{array}$ & $\begin{array}{c}\text { yes }=0 \\
\text { no }=6\end{array}$ \\
\hline
\end{tabular}

\section{Private enforcement}

44. The ability of a competition regime to deter anticompetitive behaviours is strengthened by the possibility for the damaged parties to receive financial compensation through private litigation. If private actions (started by firms, individuals, or groups of consumer directly affected by the antitrust infringement) are not authorised, the jurisdiction is scored 6 . The score is 3 if they are allowed for some antitrust infringements, 0 otherwise (Table A1.4). 
Table A1.4. Scoring of the questions on private enforcement

\begin{tabular}{lc}
\hline \multicolumn{1}{c}{ Question } & Score \\
\hline $\begin{array}{l}\text { Can individuals bring a legal action to seek damages from firms } \\
\text { that have committed an antitrust infringement? (Q12.1) }\end{array}$ & $\begin{array}{c}\text { yes }=0 \\
\text { no }=6\end{array}$ \\
$\begin{array}{lc}\text { Can firms bring a legal action to seek damages from firms that } \\
\text { have committed an antitrust infringement? (Q12.2) }\end{array}$ & $\begin{array}{c}\text { yes }=0 \\
\text { no }=6\end{array}$ \\
$\begin{array}{l}\text { Can a group of consumers (either collectively or through a } \\
\text { consumer association) bring a legal action to seek damages } \\
\text { from firms that have committed an antitrust infringement? } \\
\text { (Q12.3) }\end{array}$ & yes, but only for some antitrust infringements $=3$ \\
\end{tabular}

\section{Horizontal agreements and vertical agreements}

45. Provisions covering horizontal and vertical agreements are assessed by two separate indicators, computed as the simple average of respectively seven and four observations (Tables A1.5 and A1.6). A jurisdiction is scored 0 if horizontal/vertical agreements are prohibited. Competition regimes that carry out economic analysis of the effects of horizontal and vertical agreements and consider any efficiency they may cause are scored 0 ( 6 otherwise). Two de facto questions, which aim at measuring the enforcement of the competition law, are also included. If action has been taken against vertical or horizontal agreements at least once over the past five years, the jurisdiction is scored 0 (6 otherwise). A well-designed leniency programme is a key instrument for destabilising cartels. If a leniency programme exists and if it has generated at least one application over the last five years the jurisdiction is scored 0 (and 6 otherwise).

Table A1.5. Scoring of the questions on horizontal agreements

\begin{tabular}{lc}
\hline \multicolumn{1}{c}{ Question } & Score \\
\hline $\begin{array}{l}\text { Are anticompetitive horizontal agreements (including cartels) } \\
\text { prohibited in your jurisdiction? (Q6.1) }\end{array}$ & yes $=0$ \\
& no $=6$ \\
Does the decision-maker conduct an economic analysis of the & yes $=0$ \\
competitive effects of horizontal agreements when investigating them? & yes, but not in the case of cartels $=0$ \\
(Q6.2) & no $=6$ \\
When investigating an allegedly anticompetitive horizontal agreement & not applicable $=6$ \\
can the decision-maker consider any efficiency this may generate? & yes $=0$ \\
(Q6.3) & yes, but not in the case of cartels $=0$ \\
& no $=6$ \\
Have sanctions and/or remedies been imposed on at least one cartel & not applicable $=6$ \\
in your jurisdiction in the last five years? (Q6.4) & yes $=0$ \\
Have sanctions and/or remedies been imposed on at least one & no $=6$ \\
anticompetitive agreement that is not a cartel in your jurisdiction in the & not applicable $=6$ \\
last five years (Q6.5)? & yes $=0$ \\
Does your jurisdiction have a leniency/immunity programme for cartel & no $=6$ \\
participants (firms and/or individuals)? (Q6.6) & not applicable $=6$ \\
If yes, has the leniency/immunity programme generated at least one & yes $=0$ \\
application in the last five years? (Q6.7) & no $=6$ \\
\hline
\end{tabular}


Table A1.6. Scoring of the questions on vertical agreements

\begin{tabular}{lc}
\hline \multicolumn{1}{c}{ Question } & Score \\
\hline $\begin{array}{l}\text { Are anticompetitive vertical agreements prohibited in your } \\
\text { jurisdiction? (Q7.1) }\end{array}$ & $\begin{array}{c}\text { yes }=0 \\
\text { no }=6\end{array}$ \\
$\begin{array}{lc}\text { yes }=0 \\
\text { Does the decision-maker conduct an economic analysis of the } \\
\text { competitive effects of vertical agreements when investigating them? }\end{array}$ & $\begin{array}{c}\text { yes, but not in the case of hard-core } \\
\text { vertical agreements }=0 \\
\text { no }=6\end{array}$ \\
& $\begin{array}{c}\text { not applicable }=6 \\
\text { yes }=0\end{array}$ \\
$\begin{array}{l}\text { When investigating an allegedly anticompetitive vertical agreement } \\
\text { can the decision-maker consider any efficiencies this may generate? } \\
\text { (Q7.3) }\end{array}$ & $\begin{array}{c}\text { yes, but not in the case of hard core } \\
\text { vertical agreements }=0 \\
\text { no }=6\end{array}$ \\
$\begin{array}{l}\text { Have sanctions and/or remedies been imposed on at least one } \\
\text { anticompetitive vertical agreement in your jurisdiction in the last five } \\
\text { years? (Q7.4) }\end{array}$ & $\begin{array}{c}\text { not applicable }=6 \\
\text { yes }=0 \\
\text { no }=6\end{array}$ \\
\hline
\end{tabular}

Merger control regime

46. The indicator on merger control is based on three questions (Table A1.7). It assesses whether an economic analysis is performed to determine when to clear or block a merger and whether efficiencies are taken into account in the assessment of the merger. If an economic analysis is performed, if efficiencies are taken into account, the jurisdiction is scored 0 ( 6 otherwise). Also the jurisdiction is scored 0 if at least one merger has been blocked or cleared it with remedies over the past five years.

Table A1.7. Scoring of the questions on mergers

\begin{tabular}{lc}
\hline \multicolumn{1}{c}{ Question } & Score \\
\hline $\begin{array}{lc}\text { Does the decision-maker conduct an economic analysis of the competitive effects of } \\
\text { mergers when investigating them? (Q5.1) }\end{array}$ & $\begin{array}{c}\text { yes }=0 \\
\text { no }=6\end{array}$ \\
$\begin{array}{lc}\text { When assessing a merger can the decision-maker consider whether the merger is } & \text { yes }=0 \\
\text { likely to generate efficiencies? (Q5.2) } & \text { no }=6 \\
\text { Has the decision-maker blocked or cleared with remedies at least one merger in the } & \text { yes }=0 \\
\text { last five years? (Q5.3) } & \text { no }=6\end{array}$ \\
\hline
\end{tabular}

\section{Exclusionary conducts}

47. The indicator on exclusionary conducts is based on five questions (Table A1.8). Exclusionary conducts can be defined as business practices by a dominant firm that result in effective access of actual or potential competitors to supplies or markets being hampered or eliminated. For instance, practices that might strengthen or establish entry barriers, predatory pricing, tying and bundling, refusal to supply and rebates may be exclusionary. If exclusionary behaviours by dominant firms are prohibited, if sanctions or remedies have been imposed on a firm for this motive at least once over the past five years, the jurisdiction is scored 0 (6 otherwise). Jurisdictions are also assessed on whether an economic analysis is performed and on whether efficiencies are taken into account in the assessment of the exclusionary conduct (they are scored 0 if yes and 6 otherwise). 
Table A1.8. Scoring of the questions on exclusionary conducts

\begin{tabular}{lc}
\hline \multicolumn{1}{c}{ Question } & Score \\
\hline $\begin{array}{lc}\text { Are exclusionary conducts by dominant firms and/or by firms with substantial market } & \text { yes }=0 \\
\text { power prohibited in your jurisdiction? (Q.8.1) } & \text { no }=6 \\
\text { Does the decision-maker take non-market-share factors (such as conditions of entry, } & \text { yes }=0 \\
\text { ability of smaller firms to expand, and ability of customers to switch to smaller rivals) into } & \text { no }=6 \\
\text { account when determining dominance? (Q8.2) } & \text { not applicable }=6 \\
\begin{array}{l}\text { Does the decision-maker conduct an economic analysis of the competitive effects of } \\
\text { exclusionary conducts when investigating them? (Q8.3) }\end{array} & \text { yes }=0 \\
\text { When investigating an allegedly exclusionary conduct can the decision-maker consider } & \text { not applicable }=6 \\
\text { any efficiency this may generate? (Q8.4) } & \text { yes }=0 \\
\text { no }=6 \\
\text { Has the decision-maker in your jurisdiction imposed sanctions and/or remedies on at } \\
\text { least one firm for exclusionary conduct over the past five years? (Q8.5) }\end{array}$ \\
\hline
\end{tabular}

\section{Independence}

48. The overall score on this indicator is the simple average of six de facto components assessing whether the government has influenced the activities and decisions of the institutions that enforce competition law over the past five years (Table A1.9). A jurisdiction is scored 6 if the government has given binding directions: on the opening or closure of an investigation, on the remedies imposed for an antitrust infringements, on the market studies to be undertaken, or if it has overridden at least one decision regarding the clearance or the prohibition of a merger at least once over the past five years ( 0 otherwise). ${ }^{45}$

Table A1.9. Scoring of the questions on independence

\begin{tabular}{|c|c|}
\hline Question & Score \\
\hline $\begin{array}{l}\text { Have the government/ministers given binding directions to the competition } \\
\text { agency on whether it should open an investigation on an alleged antitrust } \\
\text { infringement at least once in the last five years? (Q2.1) }\end{array}$ & $\begin{array}{c}\text { yes }=6 \\
\text { no, because the agency has to } \\
\text { examine all the complaints it } \\
\text { receives }=0 \\
\text { no }=0\end{array}$ \\
\hline $\begin{array}{l}\text { Have the government/ministers given binding directions to the decision-maker } \\
\text { in your jurisdiction on whether it should close an investigation on an alleged } \\
\text { antitrust infringement at least once in the last five years? (Q2.2) }\end{array}$ & $\begin{array}{c}\text { yes }=6 \\
\text { no }=0\end{array}$ \\
\hline $\begin{array}{l}\text { Have the government/ministers given binding directions to the competition } \\
\text { agency on whether it should impose/not impose (or ask a court to impose/not } \\
\text { impose) specific remedies when closing an investigation on an alleged } \\
\text { antitrust infringement at least once in the last five years? (Q2.3) }\end{array}$ & $\begin{array}{c}\text { yes }=6 \\
\text { no }=0\end{array}$ \\
\hline $\begin{array}{l}\text { Have the government/ministers given binding directions to the competition } \\
\text { agency (or other public bodies) on whether it should not undertake a } \\
\text { market/sector study at least once in the last five years? (Q2.4) }\end{array}$ & $\begin{aligned} \text { yes } & =6 \\
\text { no } & =0\end{aligned}$ \\
\hline $\begin{array}{l}\text { Have the government/ministers overturned a decision concerning the } \\
\text { clearance of a merger at least once in the last five years? (Q2.5) }\end{array}$ & $\begin{array}{l}\text { yes, fully overturned }=6 \\
\text { yes, but only as regards remedies } \\
\text { imposed }=3 \\
\text { no }=0\end{array}$ \\
\hline $\begin{array}{l}\text { Have the government/ministers overturned a decision concerning the } \\
\text { prohibition of a merger or the referral of a merger for a phase } 2 \text { investigation } \\
\text { at least once in the last five years? (Q2.6) }\end{array}$ & $\begin{array}{c}\text { yes }=6 \\
\text { no }=0\end{array}$ \\
\hline
\end{tabular}

45. In the case of the UK this includes the possibility of blocking a referral from the Office of Fair Trading to the Competition Commission for a more in-depth investigation. 


\section{Accountability}

49. Four questions are related to the accountability of institutions enforcing the competition law (Table A1.10). They assess how much information on competition enforcement activities is made available to the public and whether all decisions can be subject to judicial review. The score is 0 if the agency publishes a report on its activities, if all decisions that ascertain the existence of an anticompetitive behaviours and that block or remedy mergers are published and if all antitrust decisions can be appealed. The jurisdiction is scored 6 if there is no report on the activities of the agency and if decisions are not published and cannot be appealed. If only some decisions on anticompetitive behaviours and mergers are published and not all antitrust decisions can be appealed, the score is 3 .

Table A1.10. Scoring of the questions on accountability

\begin{tabular}{lc}
\hline \multicolumn{1}{c}{ Question } & Score \\
\hline Does your competition agency regularly publish a report on its activities? (Q10.1) & $\begin{array}{c}\text { yes }=0 \\
\text { no }=6\end{array}$ \\
$\begin{array}{l}\text { Are decisions that ascertain the existence of an antitrust infringement published by the } \\
\text { relevant decision-maker? (Q10.2) }\end{array}$ & $\begin{array}{c}\text { yes, but not all }=3 \\
\text { no }=6\end{array}$ \\
$\begin{array}{l}\text { Are decisions that block a merger or clear a merger with remedies published by the } \\
\text { relevant decision-maker? (Q10.3) }\end{array}$ & $\begin{array}{c}\text { yes }=0 \\
\text { but not all }=3 \\
\text { no }=6\end{array}$ \\
$\begin{array}{l}\text { Can decisions on antitrust infringements and mergers (whether taken by a competition } \\
\text { agency or a court) be subject to judicial review with respect to their substance? (Q10.4) }\end{array}$ & $\begin{array}{c}\text { yes }=0 \\
\text { no }=6\end{array}$ \\
\hline
\end{tabular}

\section{Procedural fairness}

50. This indicator assesses whether parties under investigation have access to information on the procedures and have the possibility to present arguments for their defence. It is the simple average of ten observations (Table A1.11). If the agency publishes guidelines on procedures to help businesses and legal advice in understanding how the competition law is enforced, the jurisdiction is scored 0 (6 otherwise). Guidelines are defined as explanatory documents that help business, their legal advisers and the public to understand how the competition law will be applied. They should be separated from the law, comprehensive, and easily accessible by interested parties. For EU Member States, since the European Commission has published its own guidelines, the following rule applies: if the national competition authorities do not publish their own guidelines but rely on guidelines published by the EU Commission, the national authorities are scored 0 only if they have explicitly adopted the EU guidelines or if the law explicitly says that the authorities will interpret competition law in accordance with the principles of the European Commission. If the parties have the right to consult the agency to have information on the procedures and to be heard by the decision-making in defence of their case, the jurisdiction is scored 0 ( 6 otherwise). 
Table A1.11. Scoring of the questions on procedural fairness

\begin{tabular}{|c|c|}
\hline Question & Score \\
\hline $\begin{array}{l}\text { Does your competition agency provide the party/parties under investigation for an } \\
\text { antitrust infringement with opportunities to consult with your competition agency with } \\
\text { regard to significant legal, factual or procedural issues during the course of the } \\
\text { investigation? (Q11.1) }\end{array}$ & $\begin{array}{l}\text { yes }=0 \\
\text { no }=6\end{array}$ \\
\hline $\begin{array}{l}\text { Do parties have the right to be heard and present evidence before the imposition of } \\
\text { any sanctions or remedies for having committed an antitrust infringement? (Q11.2) }\end{array}$ & $\begin{array}{c}\text { yes }=0 \\
\text { no }=6\end{array}$ \\
\hline $\begin{array}{l}\text { Does your competition agency provide the parties under investigation for a merger with } \\
\text { opportunities to consult with your competition agency with regard to significant legal, } \\
\text { factual or procedural issues during the course of the investigation? (Q11.3) }\end{array}$ & $\begin{array}{l}\text { yes }=0 \\
\text { no }=6\end{array}$ \\
\hline $\begin{array}{l}\text { Do parties have the right to be heard and present evidence before a decision on a } \\
\text { merger is reached? (Q11.4) }\end{array}$ & $\begin{array}{l}\text { yes }=0 \\
\text { no }=6\end{array}$ \\
\hline $\begin{array}{l}\text { Does your competition agency publish procedural guidelines or public documents } \\
\text { explaining its investigative procedures? (Q11.5) }\end{array}$ & $\begin{array}{l}\text { yes }=0 \\
\text { no }=6\end{array}$ \\
\hline $\begin{array}{l}\text { Does your competition agency publish guidelines that explain how abuses of } \\
\text { dominance are assessed? (Q11.6) }\end{array}$ & $\begin{array}{c}\text { yes }=0 \\
\text { no }=6\end{array}$ \\
\hline $\begin{array}{l}\text { Does your competition agency publish guidelines that explain how horizontal } \\
\text { agreements are assessed? (Q11.7) }\end{array}$ & $\begin{array}{l}\text { yes }=0 \\
\text { no }=6\end{array}$ \\
\hline $\begin{array}{l}\text { Does your competition agency publish guidelines that explain how vertical agreements } \\
\text { are assessed? (Q11.8) }\end{array}$ & $\begin{array}{l}\text { yes }=0 \\
\text { no }=6\end{array}$ \\
\hline $\begin{array}{l}\text { Does your competition agency publish guidelines that explain how mergers are } \\
\text { assessed? (Q11.9) }\end{array}$ & $\begin{array}{l}\text { yes }=0 \\
\text { no }=6\end{array}$ \\
\hline $\begin{array}{l}\text { Are there published administrative guidelines that explain how monetary sanctions for } \\
\text { antitrust infringements are set by your competition agency, or recommended by it to } \\
\text { the court? (Q11.10) }\end{array}$ & $\begin{array}{c}\text { yes }=0 \\
\text { no }=6\end{array}$ \\
\hline
\end{tabular}

\section{Competition advocacy}

51. A competition regime can promote a pro-competitive environment also by allowing its competition agency (or another body) to advocate competition. The 'advocacy' indicator is constructed by taking the average across seven questions (Table A1.12). If the competition agency or another institution can advocate competition at the central and local levels, the jurisdiction is scored 0 ( 6 otherwise). If new regulations that may have an impact on competition are assessed to determine whether this effect is likely and find ways to reduce it, the jurisdiction is scored 0 ; if only some of these regulations are assessed, it is scored 3, otherwise it is scored 6 . A score of 0 is attributed if market studies can be performed and if they can include recommendations on how to improve competition (6 otherwise). If the government is obliged to respond to the recommendation with reasoned opinions, the jurisdiction is scored 0 . If the government is not obliged to respond to the recommendations but usually does so, the jurisdiction is scored 3 . The score is 6 if the government does not respond. 
Table A1.12. Scoring of the questions on advocacy

\begin{tabular}{|c|c|}
\hline Question & Score \\
\hline $\begin{array}{l}\text { Does your competition agency (or another public body) advocate competition at the } \\
\text { central government level? (Q9.1) }\end{array}$ & $\begin{array}{l}\text { yes }=0 \\
\text { no }=6\end{array}$ \\
\hline $\begin{array}{l}\text { Does your competition agency (or another public body) advocate competition at } \\
\text { local or regional government levels? (Q9.2) }\end{array}$ & $\begin{array}{l}\text { yes }=0 \\
\text { no }=6\end{array}$ \\
\hline $\begin{array}{l}\text { Are new public policies that may have implications for competition subject to a } \\
\text { competition assessment in your jurisdiction? (Q9.3) }\end{array}$ & $\begin{array}{c}\text { yes }=0 \\
\text { yes, but not all of them }=3 \\
\text { no }=6 \\
\text { not applicable }=6\end{array}$ \\
\hline Can market/sector studies be performed in your jurisdiction? (Q9.4) & $\begin{array}{c}\text { yes }=0 \\
\text { no }=6 \\
\text { not applicable }=6\end{array}$ \\
\hline $\begin{array}{l}\text { If yes, has at least one market/sector study been performed in your jurisdiction in the } \\
\text { last five years? (Q9.5) }\end{array}$ & $\begin{array}{c}\text { yes }=0 \\
\text { no }=6 \\
\text { not applicable }=6\end{array}$ \\
\hline $\begin{array}{l}\text { If a market/sector study identifies an obstacle or a restriction to competition caused } \\
\text { by an existing public policy, can the study include an opinion/recommendation to the } \\
\text { government to remove or reduce such an obstacle or restriction? (Q9.6) }\end{array}$ & $\begin{array}{c}\text { yes }=0 \\
\text { no }=6 \\
\text { not applicable }=6\end{array}$ \\
\hline $\begin{array}{l}\text { If a market/sector study includes an opinion/recommendation to the government } \\
\text { concerning an obstacle or restriction to competition caused by an existing public } \\
\text { policy, is the government required to publicly respond to this } \\
\text { opinion/recommendation? (Q9.7) }\end{array}$ & $\begin{array}{c}\text { yes }=0 \\
\text { no, but it usually responds }=3 \\
\text { no }=6 \\
\text { not applicable }=6\end{array}$ \\
\hline
\end{tabular}

\section{Presentation of the more aggregated set of indicators (set 1)}

52. In the first set of indicators, information is relatively more aggregated and the four indicators cover more general features of the competition policy compared to indicators in the second set but the scoring system is the same.

\section{Scope of action}

53. This indicator relates to the scope of action that enforcing bodies have in investigating, punishing and remedying anticompetitive behaviours and mergers. It is computed as the simple average of the same questions used in the indicators on 'competences', 'powers to investigate', 'powers to sanction and remedy' and 'private enforcement' from the second set.

\section{Policy on anticompetitive behaviours}

54. This indicator assesses whether anticompetitive behaviours and anticompetitive mergers are prohibited, and blocked or punished, as well as how they are assessed. It is based on questions included in the indicators 'horizontal agreements', 'vertical agreements', 'exclusionary conducts' and 'mergers' in the second set.

\section{Probity of investigation}

55. The probity of investigation is another important feature for effective competition regimes as it guarantees the soundness and fairness of the investigations. The indicator is constructed as the average of the observations contained in the indicators on 'independence', 'accountability' and 'procedural fairness'.

\section{Advocacy}

56. This indicator is the same as the indicator in the second set. 


\section{Scoring of questions that are not applicable}

57. Egypt and Luxembourg do not have a merger control regime and thus some of the questions relative to mergers cannot be answered by these jurisdictions. The treatment of these missing answers has been different depending on what each indicator is intended to measure (Table A1.13). When the questions refer to the power to sanction and remedy anticompetitive mergers, the missing answer is scored 6 . This is because the related indicators are intended to capture the powers of the institutions and not having a merger control regime is by definition a limitation of these powers. By contrast, no score is attributed to the missing answers relating to independence, procedural fairness, and accountability, because these indicators aim at assessing the enforcement of existing policies, hence if there is no merger control regime, its enforcement cannot be evaluated. These missing values are ignored when computing the indicators (i.e. the average is calculated over the available data points, adjusting the weights accordingly).

Table A1.13. Treatment of jurisdictions without merger control regime

\begin{tabular}{|c|c|}
\hline \multicolumn{2}{|l|}{ Independence } \\
\hline $\begin{array}{l}\text { Have the government/ministers overturned a decision concerning the clearance of a merger at least } \\
\text { once in the last five years? (Q2.10) }\end{array}$ & $\cdot$ \\
\hline $\begin{array}{l}\text { Have the government/ministers overturned a decision concerning the prohibition of a merger at least } \\
\text { once in the last five years? (Q2.12) }\end{array}$ & . \\
\hline \multicolumn{2}{|l|}{ Powers to investigate } \\
\hline $\begin{array}{l}\text { Can your competition agency compel (or ask a court to compel) merging firms to provide information } \\
\text { to help it assess the merger? (Q3.5) }\end{array}$ & 6 \\
\hline $\begin{array}{l}\text { Can your competition agency compel (or ask a court to compel) third parties to provide information to } \\
\text { help it assess the merger? (Q3.6) }\end{array}$ & 6 \\
\hline \multicolumn{2}{|l|}{ Powers to sanction/remedy } \\
\hline $\begin{array}{l}\text { Can your competition agency, or a court, accept or impose remedies on firms in order to clear a } \\
\text { merger? (Q4.4) }\end{array}$ & 6 \\
\hline $\begin{array}{l}\text { Can your competition agency impose, or ask a court to impose, sanctions on firms and/or individuals } \\
\text { that do not comply with a decision concerning a merger? (Q4.7) }\end{array}$ & 6 \\
\hline $\begin{array}{l}\text { Can your competition agency, or a court, clear a merger that raises anticompetitive concerns by } \\
\text { negotiating/accepting remedies that address these concerns at an early stage and thus avoid to } \\
\text { perform a more in-depth investigation? (Q4.10) }\end{array}$ & 6 \\
\hline \multicolumn{2}{|l|}{ Mergers } \\
\hline $\begin{array}{l}\text { Does the decision-maker conduct an economic analysis of the competitive effects of mergers when } \\
\text { investigating them? (Q5.1) }\end{array}$ & 6 \\
\hline $\begin{array}{l}\text { When assessing a merger can the decision-maker consider whether the merger is likely to generate } \\
\text { efficiencies? (Q5.2) }\end{array}$ & 6 \\
\hline $\begin{array}{l}\text { Has the decision-maker blocked or cleared with remedies at least one merger in the last five years? } \\
\text { (Q5.3) }\end{array}$ & 6 \\
\hline \multicolumn{2}{|l|}{ Accountability } \\
\hline \multicolumn{2}{|l|}{$\begin{array}{l}\text { Are decisions that block a merger or clear a merger with remedies published by the relevant decision- } \\
\text { maker? (Q10.3) }\end{array}$} \\
\hline \multicolumn{2}{|l|}{ Procedural fairness } \\
\hline $\begin{array}{l}\text { Does your competition agency provide the parties under investigation for a merger with opportunities } \\
\text { to consult with your competition agency with regard to significant legal, factual or procedural issues } \\
\text { during the course of the investigation? (Q11.3) }\end{array}$ & . \\
\hline $\begin{array}{l}\text { Do parties have the right to be heard and present evidence before a decision on a merger is } \\
\text { reached? (Q11.4) }\end{array}$ & $\cdot$ \\
\hline
\end{tabular}

Note: This table presents how the questions related to mergers are scored for countries which do not have a merger control regime. A dot means that no score is attributed. 
Table A1.14. CLP indicators - set 2

0 to 6 from the most to the least effective competition regime

\begin{tabular}{|c|c|c|c|c|c|c|c|c|c|c|c|c|}
\hline & $\begin{array}{l}\text { Compe- } \\
\text { tences }\end{array}$ & $\begin{array}{l}\text { Powers to } \\
\text { investigate }\end{array}$ & $\begin{array}{l}\text { Powers to } \\
\text { sanction } \\
\text { remedy }\end{array}$ & $\begin{array}{l}\text { Private } \\
\text { enforce- } \\
\text { ment }\end{array}$ & $\begin{array}{l}\text { Horizontal } \\
\text { agree- } \\
\text { ments }\end{array}$ & $\begin{array}{l}\text { Vertical } \\
\text { agree- } \\
\text { ments }\end{array}$ & Mergers & $\begin{array}{l}\text { Exclusionary } \\
\text { conducts }\end{array}$ & $\begin{array}{l}\text { Indepen- } \\
\text { dence }\end{array}$ & $\begin{array}{l}\text { Accoun- } \\
\text { tability }\end{array}$ & $\begin{array}{l}\text { Procedural } \\
\text { fairness }\end{array}$ & Advocacy \\
\hline Australia & 0.00 & 0.00 & 0.60 & 0.00 & 0.00 & 0.00 & 0.00 & 0.00 & 0.00 & 0.75 & 0.00 & 0.43 \\
\hline Austria & 0.00 & 0.00 & 0.00 & 1.00 & 0.00 & 0.00 & 0.00 & 0.00 & 0.00 & 0.75 & 1.50 & 0.86 \\
\hline Belgium & 0.00 & 0.00 & 0.00 & 1.00 & 0.00 & 0.00 & 0.00 & 0.00 & 0.00 & 0.00 & 0.00 & 0.64 \\
\hline Brazil & 0.00 & 0.00 & 0.00 & 0.00 & 0.00 & 0.00 & 0.00 & 0.00 & 0.00 & 0.00 & 0.60 & 1.29 \\
\hline Bulgaria & 0.00 & 0.00 & 0.00 & 0.00 & 0.43 & 0.00 & 1.00 & 0.00 & 0.00 & 0.00 & 0.00 & 0.86 \\
\hline Canada & 0.00 & 0.00 & 0.00 & 3.00 & 0.00 & 3.00 & 0.00 & 0.00 & 0.00 & 0.00 & 1.20 & 1.71 \\
\hline Chile & 0.00 & 0.00 & 0.60 & 1.00 & 0.00 & 1.50 & 0.00 & 0.00 & 0.00 & 0.00 & 2.40 & 1.71 \\
\hline Colombia & 0.00 & 0.00 & 0.00 & 0.00 & 0.00 & 1.50 & 0.00 & 0.00 & 0.00 & 0.00 & 2.40 & 1.71 \\
\hline Czech Republic & 0.00 & 0.00 & 0.00 & 1.00 & 0.00 & 0.00 & 0.00 & 0.00 & 0.00 & 0.00 & 0.00 & 0.43 \\
\hline Denmark & 0.00 & 0.00 & 0.60 & 0.00 & 0.00 & 0.00 & 0.00 & 0.00 & 0.00 & 0.00 & 0.00 & 0.21 \\
\hline Egypt & 0.00 & 2.00 & 3.00 & 2.00 & 2.57 & 0.00 & 6.00 & 1.20 & 0.00 & 0.00 & 5.14 & 1.71 \\
\hline Estonia & 0.00 & 0.00 & 0.30 & 0.00 & 0.00 & 0.00 & 0.00 & 0.00 & 0.00 & 0.00 & 1.80 & 0.64 \\
\hline Finland & 0.00 & 0.00 & 0.30 & 1.00 & 0.43 & 0.00 & 0.00 & 0.00 & 0.00 & 0.00 & 0.30 & 0.64 \\
\hline France & 0.00 & 0.00 & 0.00 & 0.00 & 0.00 & 0.00 & 0.00 & 0.00 & 0.00 & 0.00 & 0.00 & 0.64 \\
\hline Germany & 0.00 & 0.00 & 0.00 & 0.00 & 0.00 & 0.00 & 0.00 & 0.00 & 0.50 & 0.00 & 0.30 & 0.86 \\
\hline Greece & 0.00 & 0.00 & 0.30 & 0.00 & 0.43 & 0.00 & 0.00 & 0.00 & 0.00 & 0.00 & 0.00 & 0.64 \\
\hline Hungary & 0.00 & 0.00 & 0.00 & 0.00 & 0.00 & 0.00 & 0.00 & 0.60 & 0.50 & 0.00 & 0.90 & 0.64 \\
\hline Iceland & 0.00 & 0.00 & 0.15 & 0.00 & 0.21 & 0.00 & 0.50 & 0.00 & 0.00 & 0.00 & 0.30 & 1.61 \\
\hline India & 0.00 & 1.00 & 1.20 & 0.00 & 0.86 & 1.50 & 2.00 & 0.00 & 0.00 & 0.00 & 0.60 & 1.29 \\
\hline Indonesia & 3.00 & 2.00 & 1.80 & 0.00 & 1.71 & 0.00 & 2.00 & 0.00 & 0.00 & 0.00 & 0.00 & 1.71 \\
\hline Ireland & 0.00 & 0.00 & 0.30 & 1.00 & 0.43 & 0.00 & 0.00 & 0.60 & 0.00 & 0.00 & 0.30 & 0.43 \\
\hline Israel & 0.00 & 0.00 & 0.00 & 0.00 & 0.00 & 0.00 & 0.00 & 1.20 & 0.00 & 0.75 & 1.80 & 4.29 \\
\hline Italy & 0.00 & 0.00 & 0.30 & 0.00 & 0.00 & 0.75 & 0.00 & 0.00 & 0.00 & 0.00 & 0.00 & 0.64 \\
\hline Japan & 0.00 & 0.00 & 1.20 & 0.00 & 1.71 & 1.50 & 0.00 & 2.40 & 0.00 & 0.00 & 0.00 & 0.86 \\
\hline Korea & 0.00 & 0.00 & 0.60 & 2.00 & 0.00 & 0.00 & 0.00 & 0.00 & 0.00 & 0.00 & 0.00 & 0.43 \\
\hline Latvia & 0.00 & 0.00 & 0.30 & 1.00 & 0.00 & 0.00 & 0.00 & 0.00 & 0.00 & 0.00 & 1.50 & 0.64 \\
\hline Lithuania & 0.00 & 0.00 & 0.00 & 1.00 & 0.00 & 0.00 & 0.00 & 0.00 & 0.00 & 0.00 & 0.90 & 0.86 \\
\hline Luxembourg & 0.00 & 1.50 & 0.90 & 1.00 & 0.00 & 0.75 & 3.00 & 0.00 & 0.00 & 0.00 & 1.20 & 1.71 \\
\hline
\end{tabular}


Table A1.14. CLP indicators - set 2 (cont.)

0 to 6 from the most to the least effective competition regime

\begin{tabular}{|c|c|c|c|c|c|c|c|c|c|c|c|c|}
\hline & $\begin{array}{l}\text { Compe- } \\
\text { tences }\end{array}$ & $\begin{array}{l}\text { Powers to } \\
\text { investigate }\end{array}$ & $\begin{array}{l}\text { Powers to } \\
\text { sanction } \\
\text { remedy }\end{array}$ & $\begin{array}{c}\text { Private } \\
\text { enforce- } \\
\text { ment }\end{array}$ & $\begin{array}{l}\text { Horizontal } \\
\text { agree- } \\
\text { ments }\end{array}$ & $\begin{array}{l}\text { Vertical } \\
\text { agree- } \\
\text { ments }\end{array}$ & Mergers & $\begin{array}{l}\text { Exclusionary } \\
\text { conducts }\end{array}$ & $\begin{array}{l}\text { Indepen- } \\
\text { dence }\end{array}$ & $\begin{array}{l}\text { Accoun- } \\
\text { tability }\end{array}$ & $\begin{array}{l}\text { Procedural } \\
\text { fairness }\end{array}$ & Advocacy \\
\hline Malta & 0.00 & 0.50 & 0.30 & 0.00 & 1.29 & 0.00 & 1.00 & 0.00 & 0.00 & 0.00 & 0.30 & 1.07 \\
\hline Mexico & 0.00 & 0.00 & 0.00 & 0.00 & 0.86 & 0.00 & 0.00 & 0.00 & 0.00 & 0.00 & 0.60 & 1.29 \\
\hline Netherlands & 0.00 & 0.00 & 0.30 & 1.00 & 0.00 & 0.75 & 0.00 & 0.60 & 0.00 & 0.75 & 0.00 & 0.64 \\
\hline New Zealand & 0.00 & 1.00 & 0.00 & 0.00 & 0.00 & 0.00 & 0.00 & 0.00 & 0.00 & 0.00 & 0.00 & 0.43 \\
\hline Norway & 0.00 & 0.00 & 0.75 & 0.00 & 0.21 & 0.75 & 0.50 & 0.60 & 0.00 & 0.00 & 0.90 & 0.75 \\
\hline Peru & 0.00 & 0.00 & 0.60 & 0.00 & 0.00 & 0.00 & 2.00 & 0.00 & 0.00 & 0.00 & 3.60 & 0.86 \\
\hline Poland & 0.00 & 0.00 & 0.30 & 0.00 & 0.00 & 0.00 & 0.00 & 0.00 & 0.00 & 0.00 & 0.90 & 0.64 \\
\hline Portugal & 0.00 & 0.00 & 0.30 & 0.00 & 0.00 & 0.00 & 0.00 & 0.00 & 0.00 & 0.00 & 0.00 & 0.86 \\
\hline Romania & 0.00 & 0.00 & 0.00 & 0.00 & 0.00 & 0.00 & 0.00 & 0.00 & 0.00 & 0.00 & 0.30 & 0.64 \\
\hline Russia & 0.00 & 0.00 & 0.60 & 0.00 & 0.00 & 0.00 & 0.00 & 0.00 & 0.00 & 0.00 & 0.60 & 0.00 \\
\hline Slovakia & 0.00 & 0.00 & 0.00 & 0.00 & 0.43 & 0.75 & 0.00 & 0.00 & 0.00 & 0.00 & 0.90 & 1.07 \\
\hline Slovenia & 0.00 & 0.00 & 0.60 & 0.00 & 0.00 & 0.75 & 0.00 & 0.00 & 0.00 & 0.00 & 1.80 & 0.64 \\
\hline South Africa & 0.00 & 1.00 & 1.80 & 0.00 & 0.86 & 0.00 & 0.00 & 0.00 & 0.00 & 0.00 & 3.00 & 0.86 \\
\hline Spain & 0.00 & 0.00 & 0.00 & 0.00 & 0.00 & 0.00 & 0.00 & 0.00 & 0.25 & 0.00 & 0.00 & 0.43 \\
\hline Sweden & 0.00 & 0.00 & 0.60 & 0.00 & 0.00 & 0.00 & 0.00 & 0.00 & 0.00 & 0.00 & 1.20 & 0.86 \\
\hline Switzerland & 0.00 & 0.00 & 0.60 & 0.00 & 0.00 & 0.00 & 0.00 & 0.00 & 0.00 & 0.00 & 2.40 & 0.43 \\
\hline Turkey & 0.00 & 0.00 & 0.60 & 0.00 & 0.00 & 0.00 & 0.00 & 0.00 & 0.00 & 0.00 & 0.00 & 0.86 \\
\hline Ukraine & 0.00 & 0.00 & 0.00 & 2.00 & 1.71 & 0.00 & 0.00 & 1.20 & 0.00 & 3.00 & 2.40 & 0.43 \\
\hline United Kingdom & 0.00 & 0.50 & 0.30 & 0.00 & 0.00 & 0.00 & 0.00 & 0.00 & 0.25 & 0.00 & 0.00 & 0.21 \\
\hline United States & 1.50 & 1.00 & 0.00 & 0.00 & 0.00 & 0.00 & 0.00 & 0.00 & 0.00 & 0.00 & 1.50 & 1.29 \\
\hline OECD & 0.04 & 0.12 & 0.31 & 0.38 & 0.14 & 0.31 & 0.12 & 0.18 & 0.04 & 0.09 & 0.65 & 0.89 \\
\hline
\end{tabular}


Table A1.15. National competition laws and policies for EEA countries - set 2

0 to 6 from most to least effective competition regime

\begin{tabular}{|c|c|c|c|c|c|c|c|c|c|c|c|c|}
\hline & $\begin{array}{l}\text { Compe- } \\
\text { tences }\end{array}$ & $\begin{array}{l}\text { Powers to } \\
\text { investigate }\end{array}$ & $\begin{array}{l}\text { Powers to } \\
\text { sanction } \\
\text { remedy }\end{array}$ & $\begin{array}{c}\text { Private } \\
\text { enforce- } \\
\text { ment }\end{array}$ & $\begin{array}{l}\text { Horizontal } \\
\text { agree- } \\
\text { ments }\end{array}$ & $\begin{array}{l}\text { Vertical } \\
\text { agree- } \\
\text { ments }\end{array}$ & Mergers & $\begin{array}{l}\text { Exclusionary } \\
\text { conducts }\end{array}$ & $\begin{array}{l}\text { Indepen- } \\
\text { dence }\end{array}$ & $\begin{array}{l}\text { Accoun- } \\
\text { tability }\end{array}$ & $\begin{array}{l}\text { Procedural } \\
\text { fairness }\end{array}$ & Advocacy \\
\hline Austria & 0.00 & 0.00 & 0.00 & 2.00 & 0.00 & 0.00 & 0.00 & 0.00 & 0.00 & 1.50 & 3.00 & 1.29 \\
\hline Belgium & 0.00 & 0.00 & 0.00 & 2.00 & 0.00 & 0.00 & 0.00 & 0.00 & 0.00 & 0.00 & 0.00 & 0.86 \\
\hline Bulgaria & 0.00 & 0.00 & 0.00 & 0.00 & 0.86 & 0.00 & 2.00 & 0.00 & 0.00 & 0.00 & 0.00 & 1.29 \\
\hline Czech Republic & 0.00 & 0.00 & 0.00 & 2.00 & 0.00 & 0.00 & 0.00 & 0.00 & 0.00 & 0.00 & 0.00 & 0.43 \\
\hline Denmark & 0.00 & 0.00 & 1.20 & 0.00 & 0.00 & 0.00 & 0.00 & 0.00 & 0.00 & 0.00 & 0.00 & 0.00 \\
\hline Estonia & 0.00 & 0.00 & 0.60 & 0.00 & 0.00 & 0.00 & 0.00 & 0.00 & 0.00 & 0.00 & 3.60 & 0.86 \\
\hline Finland & 0.00 & 0.00 & 0.60 & 2.00 & 0.86 & 0.00 & 0.00 & 0.00 & 0.00 & 0.00 & 0.60 & 0.86 \\
\hline France & 0.00 & 0.00 & 0.00 & 0.00 & 0.00 & 0.00 & 0.00 & 0.00 & 0.00 & 0.00 & 0.00 & 0.86 \\
\hline Germany & 0.00 & 0.00 & 0.00 & 0.00 & 0.00 & 0.00 & 0.00 & 0.00 & 1.00 & 0.00 & 0.60 & 1.29 \\
\hline Greece & 0.00 & 0.00 & 0.60 & 0.00 & 0.86 & 0.00 & 0.00 & 0.00 & 0.00 & 0.00 & 0.00 & 0.86 \\
\hline Hungary & 0.00 & 0.00 & 0.00 & 0.00 & 0.00 & 0.00 & 0.00 & 1.20 & 1.00 & 0.00 & 1.80 & 0.86 \\
\hline Iceland & 0.00 & 0.00 & 0.00 & 0.00 & 0.00 & 0.00 & 0.00 & 0.00 & 0.00 & 0.00 & 0.60 & 1.71 \\
\hline Ireland & 0.00 & 0.00 & 0.60 & 2.00 & 0.86 & 0.00 & 0.00 & 1.20 & 0.00 & 0.00 & 0.60 & 0.43 \\
\hline Italy & 0.00 & 0.00 & 0.60 & 0.00 & 0.00 & 1.50 & 0.00 & 0.00 & 0.00 & 0.00 & 0.00 & 0.86 \\
\hline Latvia & 0.00 & 0.00 & 0.60 & 2.00 & 0.00 & 0.00 & 0.00 & 0.00 & 0.00 & 0.00 & 3.00 & 0.86 \\
\hline Lithuania & 0.00 & 0.00 & 0.00 & 2.00 & 0.00 & 0.00 & 0.00 & 0.00 & 0.00 & 0.00 & 1.80 & 1.29 \\
\hline Luxembourg & 0.00 & 3.00 & 1.80 & 2.00 & 0.00 & 1.50 & 6.00 & 0.00 & 0.00 & 0.00 & 3.43 & 3.00 \\
\hline Malta & 0.00 & 1.00 & 0.60 & 0.00 & 2.57 & 0.00 & 2.00 & 0.00 & 0.00 & 0.00 & 0.60 & 1.71 \\
\hline Norway & 0.00 & 0.00 & 0.60 & 2.00 & 0.00 & 1.50 & 0.00 & 1.20 & 0.00 & 1.50 & 0.00 & 0.86 \\
\hline Netherlands & 0.00 & 0.00 & 1.20 & 0.00 & 0.00 & 1.50 & 0.00 & 1.20 & 0.00 & 0.00 & 1.80 & 0.00 \\
\hline Poland & 0.00 & 0.00 & 0.60 & 0.00 & 0.00 & 0.00 & 0.00 & 0.00 & 0.00 & 0.00 & 1.80 & 0.86 \\
\hline Portugal & 0.00 & 0.00 & 0.60 & 0.00 & 0.00 & 0.00 & 0.00 & 0.00 & 0.00 & 0.00 & 0.00 & 1.29 \\
\hline Romania & 0.00 & 0.00 & 0.00 & 0.00 & 0.00 & 0.00 & 0.00 & 0.00 & 0.00 & 0.00 & 0.60 & 0.86 \\
\hline Slovakia & 0.00 & 0.00 & 0.00 & 0.00 & 0.86 & 1.50 & 0.00 & 0.00 & 0.00 & 0.00 & 1.80 & 1.71 \\
\hline Slovenia & 0.00 & 0.00 & 1.20 & 0.00 & 0.00 & 1.50 & 0.00 & 0.00 & 0.00 & 0.00 & 3.60 & 0.86 \\
\hline Spain & 0.00 & 0.00 & 0.00 & 0.00 & 0.00 & 0.00 & 0.00 & 0.00 & 0.50 & 0.00 & 0.00 & 0.43 \\
\hline Sweden & 0.00 & 0.00 & 1.20 & 0.00 & 0.00 & 0.00 & 0.00 & 0.00 & 0.00 & 0.00 & 2.40 & 1.29 \\
\hline United Kingdom & 0.00 & 1.00 & 0.60 & 0.00 & 0.00 & 0.00 & 0.00 & 0.00 & 0.50 & 0.00 & 0.00 & 0.00 \\
\hline
\end{tabular}




\section{ANNEX A2. FACTOR ANALYSIS}

1. This section provides some details on the factor analysis used in Section 3 of the main paper to test the sensitivity of the CLP indicators to the choice of equal weights for aggregation. Factor analysis allows identifying the contribution of each component of the regulatory framework to the overall variance of the data (each component being captured by one question in the questionnaire). The contributions can be used as weights to compute the indicators, meaning that the largest weights are assigned to those questions that have the largest variation across countries. This technique was used by Nicoletti et al. (1999) to construct the first set of PMR indicators.

2. The factor analysis is applied to the four more aggregated indicators, i.e. 'scope of action', 'policy on anticompetitive behaviours', 'probity of investigation', and 'advocacy'. Determining the contribution of each question to the variance of the data - and thus the weight of each question in the indicator - involves the following three steps:

- The first step consists in extracting so-called factors from the data using principal component analysis. This is done by regrouping questions that are highly correlated and thus redundant in orthogonal linear combinations, the factors. The analysis provides as many factors as questions. Each factor is a different linear combination of all questions and is defined by a set of coefficients ('loadings') that measure the correlation between the questions and the factor. Each factor explains a certain share of the variance of the data. Only the factors that explain a relatively large share of the variance are retained in the analysis for reasons of concision. The Kaiser criterion is used to select the factors that are retained (in our case, this is roughly equivalent to selecting the factors that jointly explain $80 \%$ of the variance).

- The second step consists of the rotation of factors. ${ }^{46}$ The rotation is a statistical technique which modifies the factors to allow for a better interpretation of the results. It limits the number of factors with which each question is highly correlated, so that a selected question can be assigned more easily to a unique factor.

- The third step consists in computing the indicators.

- First, the factors are constructed as a weighted average of the observations. Each question is weighted according to its contribution to the variance explained by the factor. This is measured by the squared loading (i.e. the variance of the question explained by the factor) normalised by the total variance explained by the factor.

- Second, the factors are aggregated to obtain the indicator. Each factor is weighted according to the proportion of the variance it explains in the total variance of the data.

3. The use of factor analysis can be illustrated with example of the indicator of scope of action. This indicator includes 21 questions, including 5 for which all jurisdictions have the same scores. The variance of the observations for these five questions is null and they are thus dropped from the analysis. As a result,

46. This is done using the varimax rotation technique, which preserves the orthogonality between the factors. 
the factor analysis is applied to 16 questions and computes 16 factors. Five factors with an eigenvalue larger than unity (Kaiser criterion) and jointly accounting for $75 \%$ of the total variance are retained (Table A2.1).

Table A2.1. Factor extraction for the indicator of scope of action

\begin{tabular}{lcccc}
\hline Factor & Eigenvalue & Difference & Proportion & Cumulative \\
\hline Factor1 & 4.42 & 1.41 & 0.28 & 0.28 \\
\hline Factor2 & 3.01 & 0.96 & 0.19 & 0.46 \\
Factor3 & 2.05 & 0.76 & 0.13 & 0.59 \\
Factor4 & 1.29 & 0.12 & 0.08 & 0.67 \\
Factor5 & 1.17 & 0.17 & 0.07 & 0.75 \\
Factor6 & 0.998 & 0.15 & 0.06 & 0.81 \\
Factor7 & 0.85 & 0.10 & 0.05 & 0.86 \\
$\ldots$ & 0.74 & 0.26 & 0.05 & 0.91 \\
Factor15 & 0.48 & 0.07 & 0.03 & 0.94 \\
\hline Factor16 & 0.41 & 0.03 & 0.03 & 0.97 \\
\hline
\end{tabular}

Note: obtained with the principle component method

4. Rotated loadings (i.e. correlation coefficients between the factors and the questions after rotation) are estimated for the five selected factors (Table A2.2). The contribution of each question to the variance explained by each factor is measured as the associated squared loading normalised by the variance explained by the factor. These weights are used to compute the factors (as the weighted sum of the observations). The indicator is finally obtained by aggregating the factors weighted by their contribution to the total variance. The contribution of each factor to the total variance is the proportion of the total variance (the sum of the eigenvalues) explained by the factor (the eigenvalue).

Table A2.2. Loadings and weights obtained for the indicator of scope of action

\begin{tabular}{l|cc|cc|c|cc}
\hline & \multicolumn{2}{|c|}{ Factor 1 } & \multicolumn{2}{c|}{ Factor 2 } & $\ldots$ & \multicolumn{2}{c}{ Factor 5 } \\
\hline Questions & $\begin{array}{l}\text { Factor } \\
\text { loadings }\end{array}$ & $\begin{array}{l}\text { Weight of } \\
\text { questions in } \\
\text { the factor }\end{array}$ & $\begin{array}{l}\text { Factor } \\
\text { loadings }\end{array}$ & $\begin{array}{l}\text { Weight of } \\
\text { questions in } \\
\text { the factor }\end{array}$ & & $\begin{array}{l}\text { Factor } \\
\text { loadings }\end{array}$ & $\begin{array}{l}\text { Weight of } \\
\text { questions in } \\
\text { the factor }^{2}\end{array}$ \\
\hline Q1.1 & -0.04 & 0.00 & 0.93 & 0.29 & & -0.11 & 0.01 \\
Q 1.2 & 0.02 & 0.00 & 0.15 & 0.01 & & 0.88 & 0.59 \\
Q 3.3 & -0.03 & 0.00 & 0.91 & 0.28 & & 0.30 & 0.07 \\
Q 3.4 & 0.04 & 0.00 & 0.63 & 0.13 & & 0.37 & 0.11 \\
Q 3.5 & 0.96 & 0.21 & -0.03 & 0.00 & & 0.04 & 0.00 \\
$\ldots$ & $\ldots$ & $\ldots$ & $\ldots$ & $\ldots$ & & $\ldots$ & $\ldots$ \\
Q 12.2 & -0.02 & 0.00 & -0.01 & 0.00 & & -0.01 & 0.00 \\
Q 12.3 & 0.48 & 0.05 & -0.12 & 0.00 & & -0.13 & 0.01 \\
\hline
\end{tabular}

1. Obtained after rotation.

2. Contribution of the questions to the variance explained by the factors, measured as the squared factor loading normalised by the variance explained by the factor (the eigenvalue).

3. Contribution of the factor to the total variance explained by the five factors measured as the ratio between the variance explained by the factor and the sum of the variance of the five factors selected. 
ECO/WKP(2013)96

\section{WORKING PAPERS}

The full series of Economics Department Working Papers can be consulted at www.oecd.org/eco/workingpapers/

1103. The effect of government debt, external debt and their interaction on OECD interest rates (December 2013) by David Turner and Francesca Spinelli

1102. The state of the banking sector in Europe

(December 2013) by Dirk Schoenmaker and Toon Peek

1101. Getting Irish youth on the job track

(December 2013) by Alberto González Pandiella

1100. New econometric estimates of long-term growth effects of different areas of public spending (December 2013) by Omar Barbiero and Boris Cournède

1099. Cross-country spillovers from fiscal consolidations

(December 2013) by Antoine Goujard

1098. Informal employment in Russia: definitions, incidence, determinants and labour market segmentation

(December 2013) by Hartmut Lehmann and Anzelika Zaiceva

1097. Capacity needs in the automobile industry in the short- to medium run

(November 2013) by Caroline Klein and Isabell Koske

1096. Environmental policies and productivity growth - a critical review of empirical findings

(November 2013) by Tomasz Koźluk and Vera Zipperer

1095. Green growth challenges and the need for an energy reform in Mexico

(November 2013) by Carla Valdivia de Richter

1094. From bricks to brains: increasing the contribution of knowledge-based capital to growth in

Ireland

(November 2013) by David Haugh

1093. China's march to prosperity: reforms to avoid the middle-income trap

(November 2013) by Vincent Koen, Richard Herd and Sam Hill

1092. Multi factor productivity with natural capital

(November 2013) by Nicola Brandt, Paul Schreyer and Vera Zipperer

1091. Growth-promoting policies and macroeconomic stability

(November 2013) by Douglas Sutherland and Peter Hoeller

1090. Policies for inclusive urbanisation in China

(October 2013) by Vincent Koen, Richard Herd, Xiao Wang and Thomas Chalaux

1089. Fiscal devaluation - can it help to boost competitiveness?

(October 2013) by Isabell Koske 
1088. How to achieve growth- and equity-friendly fiscal consolidation? A proposed methodology for instrument choice with an illustrative application to OECD countries

(October 2013) by Boris Cournède, Antoine Goujard and Álvaro Pina

1087. Improving school-to-work transition in New Zealand

(September 2013) by Alexandra Bibbee

1086. The agri-food situation and policies in Switzerland

(September 2013) by Peter Jarrett and Charlotte Moeser

1085. Japan's challenging debt dynamics

(August 2013) by Yvan Guillemette and Jan Strasky

1084. Transitions in and out of unemployment among young people in the Irish recession

(August 2013) by Elish Kelly, Seamus McGuinness, Philip O'Connell, David Haugh and Alberto González Pandiella

1083. Is there convergence of Russia's regions? Exploring the empirical evidence: 1995-2010

(August 2013) by Hartmut Lehmann and Maria Giulia Silvagni

1082. The benefits and costs of highly expansionary monetary policy

(August 2013) by Łukasz Rawdanowicz, Romain Bouis and Shingo Watanabe

1081. The effectiveness of monetary policy since the onset of the financial crisis

(August 2013) by Romain Bouis, Łukasz Rawdanowicz, Jean-Paul Renne, Shingo Watanabe and Ane Kathrine Christensen

1080. Responding to key well-being challenges in Austria

(August 2013) by Rauf Gönenç, Oliver Röhn, Christian Beer and Andreas Wörgötter

1079. Austria's well-being goes beyond GDP

(August 2013) by Oliver Röhn, Rauf Gönenç, Christian Beer and Romina Boarini

1078. Improving fiscal federal relations for a stronger Mexico

(August 2013) by Aida Caldera Sánchez

1077. Deleveraging: challenges, progress and policies

(August 2013) by Romain Bouis, Ane Kathrine Christensen and Boris Cournède

1076. Policies to support sustainable long-term growth in New Zealand

(July 2013) by Calista Cheung

1075. Do structural policies affect macroeconomic stability?

(July 2013) by Volker Ziemann

1074. A simple fiscal stress testing model - case studies of Austrian, Czech and German economies (July 2013) by Ondra Kamenik, Zdenek Tuma, David Vavra and Zuzana Smidova

1073. Road connectivity and the border effect: evidence from Europe

(July 2013) by Henrik Braconier and Mauro Pisu 